\title{
Caffeic Acid Phenyl Ester (CAPE) Protects against Iron-Mediated Cellular DNA Damage through Its Strong Iron-Binding Ability and High Lipophilicity
}

\author{
Bo Shao ${ }^{1,2} \mathbb{D}$, Li Mao ${ }^{2,3, *}$, Miao Tang ${ }^{2,3}$, Zhu-Ying Yan ${ }^{2,3}$, Jie Shao ${ }^{2,3} \mathbb{D}$, Chun-Hua Huang ${ }^{2,3}$, Zhi-Guo Sheng ${ }^{2,3}$ \\ and Ben-Zhan Zhu $2,3,4, *$
}

check for

updates

Citation: Shao, B.; Mao, L.; Tang, M.; Yan, Z.-Y.; Shao, J.; Huang, C.-H.;

Sheng, Z.-G.; Zhu, B.-Z. Caffeic Acid Phenyl Ester (CAPE) Protects against Iron-Mediated Cellular DNA Damage through Its Strong Iron-Binding Ability and High Lipophilicity. Antioxidants 2021, 10, 798. https:// doi.org/10.3390/antiox10050798

Academic Editor: Alexandros G. Georgakilas

Received: 13 April 2021

Accepted: 11 May 2021

Published: 18 May 2021

Publisher's Note: MDPI stays neutral with regard to jurisdictional claims in published maps and institutional affiliations.

Copyright: (c) 2021 by the authors. Licensee MDPI, Basel, Switzerland. This article is an open access article distributed under the terms and conditions of the Creative Commons Attribution (CC BY) license (https:/ / creativecommons.org/licenses/by/ $4.0 /)$.
1 Department of Public Health, Jining Medical University, Jining 272067, China; shaobo@mail.jnmc.edu.cn

2 State Key Laboratory of Environmental Chemistry and Ecotoxicology, Research Center for Eco-Environmental Sciences, The Chinese Academy of Sciences, Beijing 100085, China; miaotang_st@rcees.ac.cn (M.T.); zyyan_st@rcees.ac.cn (Z.-Y.Y.); jieshao@rcees.ac.cn (J.S.); chhuang@rcees.ac.cn (C.-H.H.); zgsheng@rcees.ac.cn (Z.-G.S.)

3 University of Chinese Academy of Sciences, Beijing 100085, China

4 Joint Institute for Environmental Science, Research Center for Eco-Environmental Sciences and Hong Kong Baptist University, Beijing 100085/Hong Kong 999077, China

* $\quad$ Correspondence: limao@rcees.ac.cn (L.M.); bzhu@rcees.ac.cn (B.-Z.Z.); Tel.: +86-10-62849030 (B.-Z.Z.)
Abstract: Caffeic acid phenethyl ester (CAPE) and its structurally-related caffeic acid (CA), ferulic acid (FA) and ethyl ferulate (EF) are constituents of honeybee propolis that have important pharmacological activities. This study found that CAPE-but not CA, FA, and EF-could effectively prevent cellular DNA damage induced by overloaded iron through decreasing the labile iron pool (LIP) levels in HeLa cells. Interestingly, CAPE was found to be more effective than CA in protecting against plasmid DNA damage induced by $\mathrm{Fe}(\mathrm{II})-\mathrm{H}_{2} \mathrm{O}_{2}$ or $\mathrm{Fe}(\mathrm{III})$-citrate-ascorbate- $\mathrm{H}_{2} \mathrm{O}_{2}$ via the inhibition of hydroxyl radical $(\bullet \mathrm{OH})$ production. We further provided more direct and unequivocal experimental evidences for the formation of inactive CAPE/CA-iron complexes. CAPE was found to have a stronger iron-binding ability and a much higher lipophilicity than CA. Taken together, we propose that the esterification of the carboxylic moiety with phenethyl significantly enhanced the iron-binding ability and lipophilicity of CAPE, which is also responsible for its potent protection against iron-mediated cellular DNA damage. A study on the iron coordination mechanism of such natural polyphenol antioxidants will help to design more effective antioxidants for the treatment and prevention of diseases caused by metal-induced oxidative stress, as well as help to understand the structure-activity relationships of these compounds.

Keywords: caffeic acid phenethyl ester; iron; DNA damage; hydroxyl radical; redox-inactive iron complex; lipophilicity

\section{Introduction}

Iron is essential for life due to the efficiency with which it converts between its $\mathrm{Fe}(\mathrm{II})$ and $\mathrm{Fe}(\mathrm{III})$ redox states. Iron participates in oxygen transport, DNA synthesis, electron transport, and many other biological processes. However, iron overload could cause several adverse effects in many biological systems [1-3]. In humans, an increase of cellular-free iron has close relationships with stroke, aging, Alzheimer's, Parkinson's, and cardiovascular diseases [4-6]. Highly reactive $\bullet \mathrm{OH}$ formation via Fenton reactions is critical for excessive iron-mediated cell damage [7-13]. $\bullet \mathrm{OH}$ could induce protein, lipid, and DNA damage, which comprise one of the major sources of oxidative stress $[14,15]$. Iron-induced DNA damage through $\bullet \mathrm{OH}$ is closely related to the cellular death and tissue damage caused by several diseases as mentioned above. Thus, the inhibition of iron-induced DNA damage by $\bullet \mathrm{OH}$ has important biological significance for the prevention of diseases. 
Polyphenol compounds widely found in tea, fruits, and vegetables have been considered to be good antioxidants [16-18]. Both the scavenging of ROS and metal binding by polyphenols are major mechanisms of their antioxidant activity, especially the metalbinding ability [19-24]. Tannic acid was found to prevent the Fenton reaction by chelating $\mathrm{Fe}^{2+}$ [25]. Polyphenols also could prevent nuclear DNA damage induced by iron through the metal-binding ability, and catechol derivatives have exhibited more antioxidant properties than those without the catechol moiety [26].

Hydroxycinnamic acid is an important subgroup of phenolic compounds that is widely found in plants and plant products [27]. They have significant antioxidant activity both in vitro and in vivo $[27,28]$. Recently, caffeic acid phenethyl ester (CAPE), which was extracted from propolis, was found to have interesting pharmacological activity. CAPE may play an important role in the chemo-preventive and anti-tumor properties of propolis $[29,30]$. CAPE has also been shown to prevent lipid peroxidation in the spinal cord and brain [31,32]. An extract of propolis with CAPE was found to have more potent antioxidant activity than an extract without CAPE [33]. Though attempts have been made to investigate the mechanism of the antioxidant property of CAPE, few detailed studies have ever been done on its metal-chelating characteristic and protection against iron-mediated cellular DNA damage via $\bullet \mathrm{OH}$ production. Because of the catechol-moiety of CAPE, we speculate that metal-chelating character may play a key role in its antioxidant activity.

Therefore, this study was designed to address the following questions: Can CAPE and its analogues including CA, FA, and EF prevent iron-mediated DNA damage from -OH in cellular DNA (Figure 1), and if so, what is the underlying molecular mechanism?<smiles>COc1ccc(/C=C/C(=O)O)cc1O</smiles>

FA<smiles>COC(=O)/C=C/c1ccc(O)c(O)c1</smiles>

CAME<smiles>O=C(O)/C=C/c1ccc(O)c(O)c1</smiles>

CA<smiles>CCOC(=O)/C=C/c1ccc(OC)c(O)c1</smiles>

EF<smiles>CCOC(=O)/C=C/c1ccc(O)c(O)c1</smiles>

CAEE

Figure 1. Structural formulas of CAPE, CA, FA, EF, CAME, and CAEE.

\section{Materials and Methods}

\subsection{Materials}

CAPE (97\%), CA (98\%), FA (98\%), EF (98\%), caffeic acid methyl ester (CAME) (98\%), caffeic acid ethyl ester (CAEE) (98\%), calf thymus DNA (ct-DNA), ascorbic acid, and bovine serum albumin (BSA) were purchased from Sigma (St. Louis, MO, USA). Ferric chloride $(\geq 99 \%)$, ferrous ammonium sulfate hexahydrate $(\geq 99.5 \%)$, and trisodium citrate dihydrate $(\geq 99.5 \%)$ were purchased from Sinopharm Chemical Reagent Co., Ltd. Calcein and calcein-AM were purchased from MedChemExpress (MCE). 5,5-dimethyl-1-pyrroline $\mathrm{N}$-oxide (DMPO) was purchased from DOJINDO Molecular Technologies.

\subsection{Immunofluorescence Analysis of Intracellular $\gamma-H 2 A X$ Generation in HeLa Cells}

The immortalized human cervical carcinoma HeLa cell line used in this study was obtained from the Cell Resource Center, Peking Union Medical College. The cell line was checked to be free of mycoplasma contamination by PCR and culture. Its species origin was confirmed with PCR. The identity of the cell line was authenticated with STR profiling (FBI, CODIS). HeLa cells were cultured in a DMEM medium (4 mM L-glutamine, 
$4500 \mathrm{mg} / \mathrm{L}$ glucose, and no sodium pyruvate) with $10 \%$ fetal bovine serum (FBS) and $1 \%$ penicillin-streptomycin at $37^{\circ} \mathrm{C}$ under a $5 \% \mathrm{CO}_{2}$ atmosphere.

HeLa cells $\left(10^{4} /\right.$ well) were loaded by incubation with $20 \mu \mathrm{M} \mathrm{Fe}(\mathrm{II})$ for $2 \mathrm{~h}$ at $37^{\circ} \mathrm{C}$. Subsequently, cells were incubated with or without $20 \mu \mathrm{M}$ CAPE and its analogues for $30 \mathrm{~min}$, and then they were incubated with $100 \mu \mathrm{M} \mathrm{H}_{2} \mathrm{O}_{2}$ for $30 \mathrm{~min}$ before fixation by $100 \%$ ice-cold methanol for $5 \mathrm{~min}$. For a detailed experimental procedure, please refer to the Supplementary Materials and our previous report [34]. The experiment was repeated three times. The observation of the fluorescence of $\gamma-\mathrm{H} 2 \mathrm{AX}$ in HeLa cells was conducted with a confocal laser scanning microscope (CLSM) (Leica TCS SP). Thirty cells in each group were randomly selected in different microscopic fields for quantitative detection. In detail, each well was equally divided into nine fields and numbered sequentially from the top right corner. Four fields were randomly selected according to a random number table. Thirty cells were then randomly selected from these four fields. All images were analyzed blind regarding exposure parameters, which were coded by one person and read by another who was blinded to the code. The fluorescence intensity of the $\gamma$-H2AX signal on selected images was automatically analyzed using the Image-J software. The Statistical Product and Service Solutions (SPSS 21) program was employed to analyze the data through ANOVA. Significant difference from iron-overloaded group are marked with ${ }^{*} p<0.05,{ }^{* *} p<0.01$, and ${ }^{* * *} p<0.001$.

\subsection{Labile Iron Pool (LIP) Determination}

HeLa cells $\left(10^{6} / \mathrm{mL}\right)$ were loaded by incubation with $20 \mu \mathrm{M} \mathrm{Fe}(\mathrm{II})$ for $2 \mathrm{~h}$ at $37^{\circ} \mathrm{C}$. Subsequently, cells were collected by centrifugation (1000 rpm for $5 \mathrm{~min}$ ) and incubated with $0.5 \mu \mathrm{M}$ calcein-AM for $15 \mathrm{~min}$ at $37^{\circ} \mathrm{C}$ in a D'hanks buffer of $\mathrm{pH}$ 7.4. Cells were then washed twice by D'hanks buffer ( $\mathrm{pH}$ 7.4) and incubated with or without CAPE and its analogues. The fluorescence was monitored by both flow cytometry (BD FACS Caliber) and a CLSM (Leica TCS SP). The experiment was repeated three times.

\subsection{DNA Strand Breakage}

Plasmid DNA agarose gel electrophoresis [35] was employed to investigate protective effect of CAPE and its analogues against DNA strand breakage induced by an iron-mediated system. For experimental procedure details, please refer to the Supplementary Materials.

\subsection{Electron Spin Resonance (ESR) Spin-Trapping Studies}

The basic system used in this study consisted of $\mathrm{Fe}(\mathrm{III}) / \mathrm{Fe}(\mathrm{II})$, ascorbate, $\mathrm{H}_{2} \mathrm{O}_{2}$, and the spin trapping agent DMPO $(100 \mathrm{mM})$ in $20 \mathrm{mM}$ HEPES (pH 7.4) with or without CAPE and its analogues. For typical parameters, please refer to the Supplementary Materials.

\subsection{UV-Visible Spectra Measurement}

The reaction mixture involved different concentrations of CAPE and Fe(III)-citrate in $20 \mathrm{mM}$ HEPES ( $\mathrm{pH}$ 7.4). For the detailed experimental procedure, please refer to our previous report [35].

\subsection{Calcein Fluorescence Detection}

In the presence of calcein, mixtures of CAPE and $\mathrm{Fe}(\mathrm{III}) / \mathrm{Fe}(\mathrm{II})$ with different concentrations in $20 \mathrm{mM}$ HEPES ( $\mathrm{pH} 7.4$ ) were used for fluorescence detection (Ex: $488 \mathrm{~nm}$; Em: $515 \mathrm{~nm}$ ). Fluorescence spectra were recorded using a Cary Eclipse fluorescence spectrophotometer (Varian, Palo Alto, CA, USA).

\subsection{Fourier Transform Ion Cyclotron Resonance Mass (FT-ICR-MS) Detection}

The formation of CAPE/CA-Fe(III) complexes was detected by FT-ICR-MS (Bruker Daltonik, $\mathrm{GmbH}$, Bremen, Germany). For the detailed experimental procedure, please refer to the Supplementary Materials and our previous study [35]. 


\subsection{Measurement of the Fe(III)-Binding Affinity with Ligands Including CAPE, CA, CAME,} and CAEE

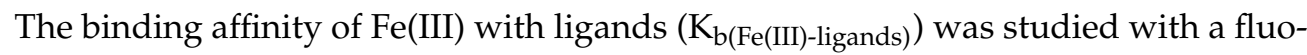
rescence displacement method using calcein as the fluorescent agent. As we know, calcein can be used as a fluorescence probe due to the fluorescence quenching upon interaction with iron. When ligands compete to bind iron from calcein, the fluorescence quenching of calcein-iron is inhibited. Thus, calcein was used as fluorescent probe here to measure the iron-binding affinity. In the solution (100 mM PB at pH7.4), $\mathrm{Fe}(\mathrm{III})$ and calcein were kept at 0.5 and $20 \mu \mathrm{M}$, respectively. $\mathrm{IC}_{50}$ represents the $50 \%$ inhibitory concentration of each ligand. The binding constants between each ligand and $\mathrm{Fe}(\mathrm{III})$ were calculated with the following equation [36,37]:

$$
\begin{gathered}
K_{\mathrm{d}}=\left[I C_{50}\right] /\left(1+[\text { probe }] / K_{\text {Probe }(\text { Calcein })}\right) \\
K_{\mathrm{b}(\mathrm{Fe}(\mathrm{III})-\text { Ligand })}=\frac{1}{K d}
\end{gathered}
$$

where [probe] is the concentration of calcein $(0.5 \mu \mathrm{M})$ and the intrinsic calcein-binding constant $K_{\mathrm{b} \text { (Fe(III)-Calcein) }}$ of $\mathrm{Fe}(\mathrm{III})$ is $10^{24} \mathrm{M}^{-1}$. $K_{\text {probe(Calcein) }}$ is the dissociation constant for the intercalation of $\mathrm{Fe}(\mathrm{III})$ with calcein, so $K_{\text {probe(Calcein) }}=1 / 10^{24} \mathrm{M}^{-1}$.

\subsection{Cyclic Voltammetry (CV) Measurement}

CV was performed in 100 mM PB (pH 7.4) on a Princeton Applied Research (VersaSTAT3) potentiostat with a $\mathrm{Pt}$ wire as the counter electrode, a saturated calomel electrode (SCE) as the reference electrode, and a glassy carbon electrode (5 $\mathrm{mm}$ in diameter) as the working electrode. The scan rate was $2 \mathrm{mV} / \mathrm{s}$.

\subsection{Partitioning Study}

Organic solvents (1-octanol)/aqueous (100 $\mathrm{mM}$ phosphate buffer at $\mathrm{pH} 7.4)$ phase partition for CAPE and its analogues were conducted using the shake-flask method [38], with the concentration in each phase determined by a Cary 3500 UV-Vis spectrophotometer (Agilent, Santa Clara, CA, USA).

\subsection{Statistical Analysis}

All experiments were repeated three times. For the figures showing immunofluorescence staining and LIP quantitative analysis, the data were obtained from three parallel experiments. The fluorescence intensities were divided by control group, and the fold values compared to control were analyzed by the SPSS 21 program. ANOVA followed by a least significant difference (LSD) test $(p<0.05,0.01$, or 0.001 ) was employed to determine significant differences between different treatments. Significant differences from $\mathrm{Fe}(\mathrm{II})-\mathrm{H}_{2} \mathrm{O}_{2}$ group were marked with ${ }^{*} p<0.05,{ }^{* *} p<0.01$, or ${ }^{* * *} p<0.001$. For the data showing ESR spectra, MS spectra, fluorescence spectra, and UV-Vis absorption spectra, the experiments were repeated three times, and only typical spectra are presented.

\section{Results and Discussion}

\subsection{CAPE Was Found to Be the Most Potent in Protecting Against Iron-Mediated Cellular DNA Damage}

It is well-known that iron-induced DNA damage through $\bullet \mathrm{OH}$ is closely related to oxidative stress and cellular death, which might induce tissue damage and several diseases [1,4-6]. We first investigated whether CAPE and its analogues could inhibit cellular DNA damage induced by an iron-overload system in HeLa cells [39]. As shown in Figure 2, neither iron overload nor $\mathrm{H}_{2} \mathrm{O}_{2}$ alone could induce significant cellular DNA damage, while double strands breaks (DSBs) were obviously produced in iron-overloaded cells in the presence of $\mathrm{H}_{2} \mathrm{O}_{2}$. Interestingly, the pre-treatment of 2-50 $\mu \mathrm{M} \mathrm{CAPE}$ could significantly inhibit the cellular DNA damage induced by iron overload (with $\mathrm{H}_{2} \mathrm{O}_{2}$ ) in a concentration-dependent manner. The results observed from $\mathrm{Fe}(\mathrm{II})-\mathrm{H}_{2} \mathrm{O}_{2}-20 \mu \mathrm{M}$ 
CAPE and $\mathrm{Fe}(\mathrm{II})-\mathrm{H}_{2} \mathrm{O}_{2}-50 \mu \mathrm{M}$ CAPE exhibited significant differences with the $\mathrm{Fe}(\mathrm{II})-\mathrm{H}_{2} \mathrm{O}_{2}$ group. In contrast, for CA (one of CAPE analogues), only $500 \mu \mathrm{MCA}$ could provide similar protection against DNA damage induced by iron overload (with $\mathrm{H}_{2} \mathrm{O}_{2}$ ). However, for another two CAPE analogues (FA and EF), no significant inhibition could be observed (Figure S1).

$\mathbf{A}$

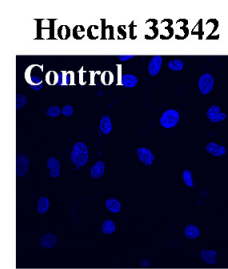

$50 \mu \mathrm{M} \mathrm{Fe}(\mathrm{II})$

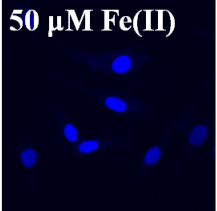

$100 \mu \mathrm{M} \mathrm{H}_{2} \mathrm{O}_{2}$

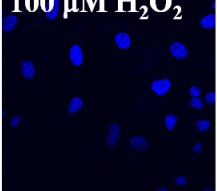

$\mathrm{Fe}(\mathrm{III})-\mathrm{H}_{2} \mathrm{O}_{2}$

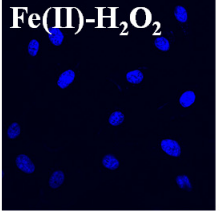

No CAPE or CA
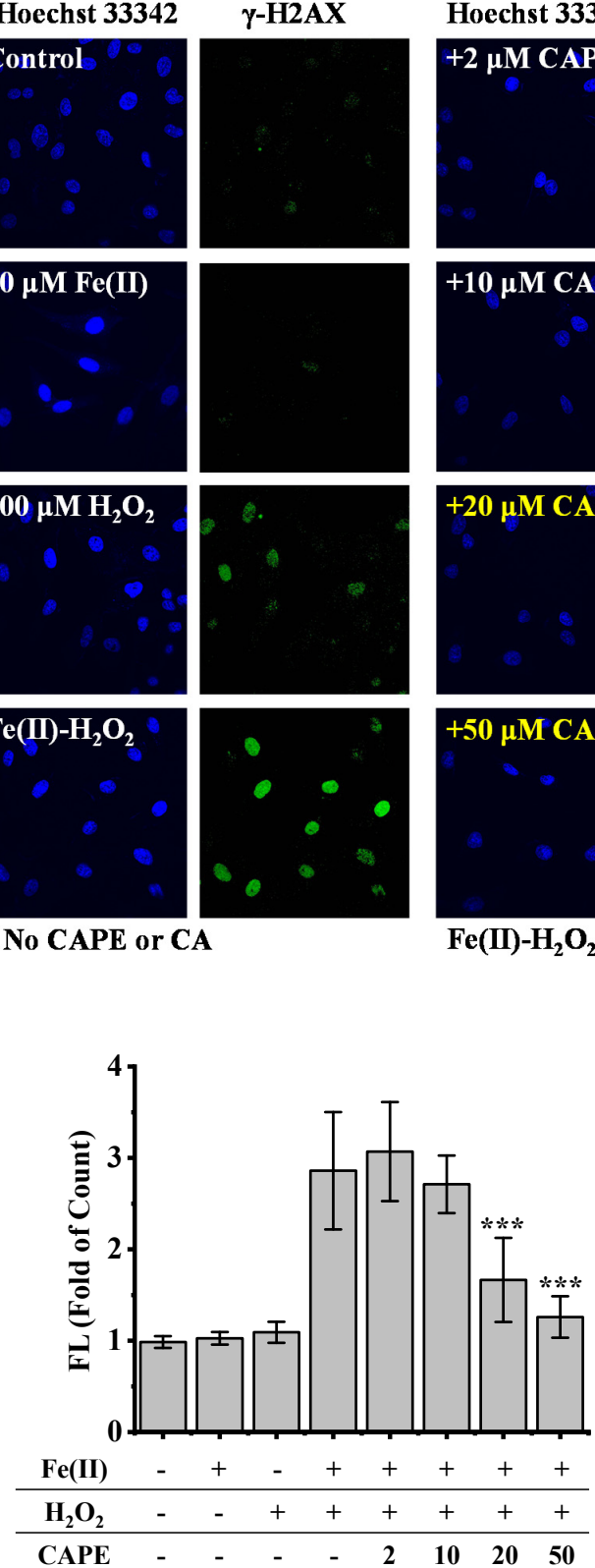

$\gamma-\mathrm{H} 2 \mathrm{AX}$
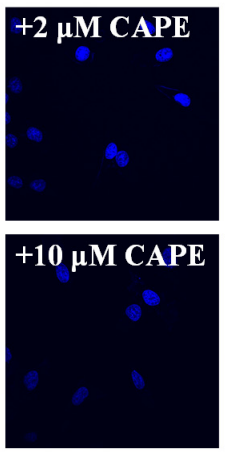

$+20 \mu \mathrm{M}$ CAPE

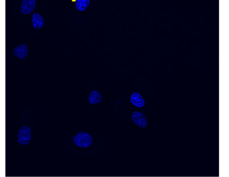

$+50 \mu \mathrm{M}$ CAPE

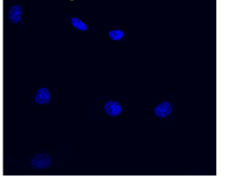

$\mathrm{Fe}(\mathrm{II})-\mathrm{H}_{2} \mathrm{O}_{2}$
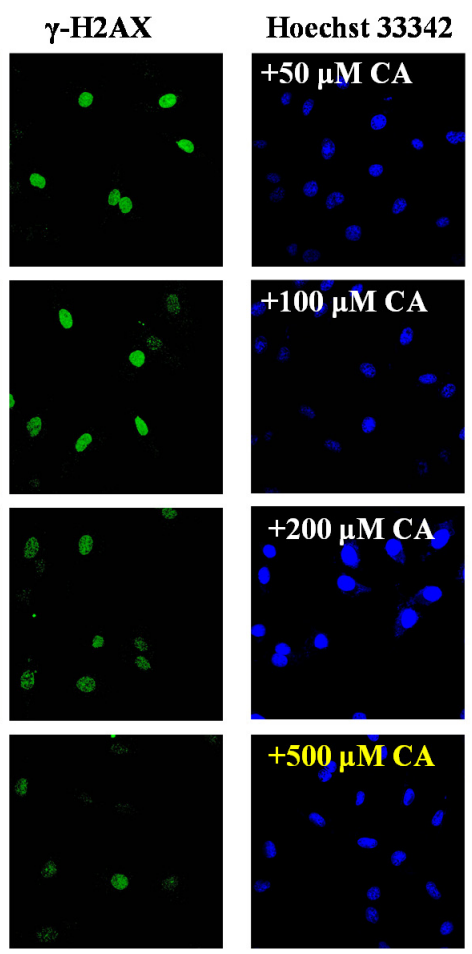

$\mathrm{Fe}(\mathrm{II})-\mathrm{H}_{2} \mathrm{O}_{2}$
$\gamma-\mathrm{H} 2 \mathrm{AX}$
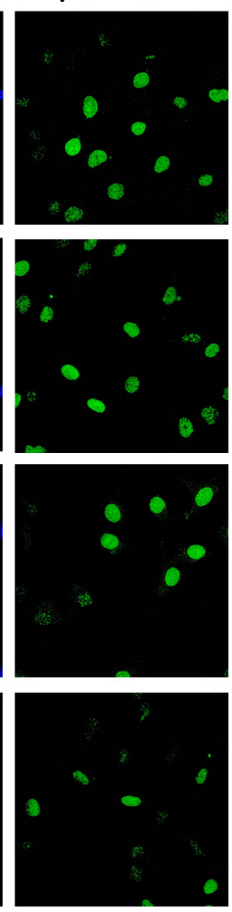

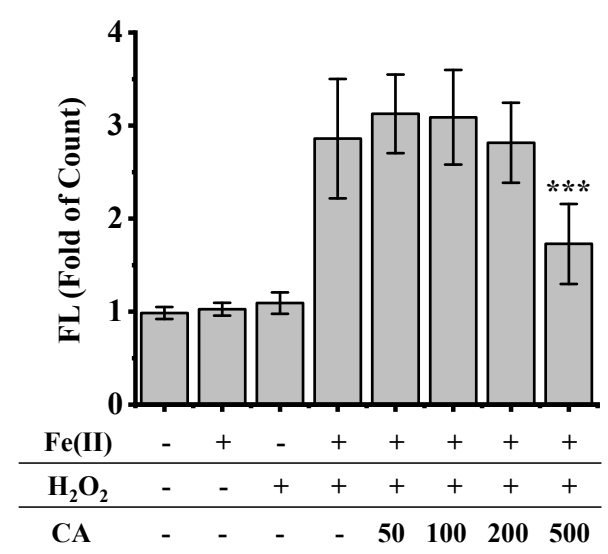

Figure 2. Inhibition of CAPE and its analogues on the formation of $\gamma$-H2AX induced by iron-overload in HeLa cells, as measured by immunofluorescence staining. (A) Representative images of HeLa cells stained for Hoechst 33342 (nuclear stain) monoclonal antibodies of $\gamma-\mathrm{H} 2 \mathrm{AX}$ under different conditions as indicated. (B) Quantitation of $\gamma$-H2AX formation in HeLa cells under different conditions as indicated. ${ }^{* * *}$ Significant difference from the $\mathrm{Fe}(\mathrm{II})-\mathrm{H}_{2} \mathrm{O}_{2}$ groups, $p<0.001$. The experiment was repeated three times, and thirty cells were randomly selected in different microscopic fields for statistical analysis in each group. 


\subsection{CAPE Was Found to Be the Most Potent in Decreasing LIP Levels Induced by Iron Overload}

Previous reports suggested that the catechol group might play a critical role in the metal-binding ability. We speculated that the inhibition of CAPE on the oxidatively generated DNA damage might have been due to its ability to chelate overloaded iron and inhibit its redox activity. Therefore, we further studied the level of LIP in iron-overloaded HeLa cells pre-treated with or without CAPE and its analogues.

LIP was first proposed as a transition pool between extracellular iron and proteinrelated cellular iron [40], which can participate in the redox cycle but can be eliminated by the chelating agent. Though the level of LIP can change dynamically with stimulation, the changes are temporary and homeostatic. However, in the case of iron overload or deprivation, these changes may disrupt cell homeostasis and compromise its integrity [41].

As shown by both confocal laser scanning microscopy and flow-cytometry, the pretreatment of $\mathrm{Fe}$ (II) for $2 \mathrm{~h}$ significantly decreased the fluorescence intensity of calcein, which indicated the increase of LIP in HeLa cells (Figure 3 and Figure S2). However, the fluorescence significantly regenerated after the addition of 20-50 $\mu \mathrm{M}$ CAPE $(p<0.001)$, which suggested that a low concentration of CAPE could decrease the LIP levels, possibly by chelating with LIP (Figure 3). In contrast, a much higher concentration of CA (500 $\mu \mathrm{M})$ was required to increase the fluorescence $(p<0.05)$, while no effect was observed with EF and FA $(50-500 \mu \mathrm{M})$ (Figure 3B-D).
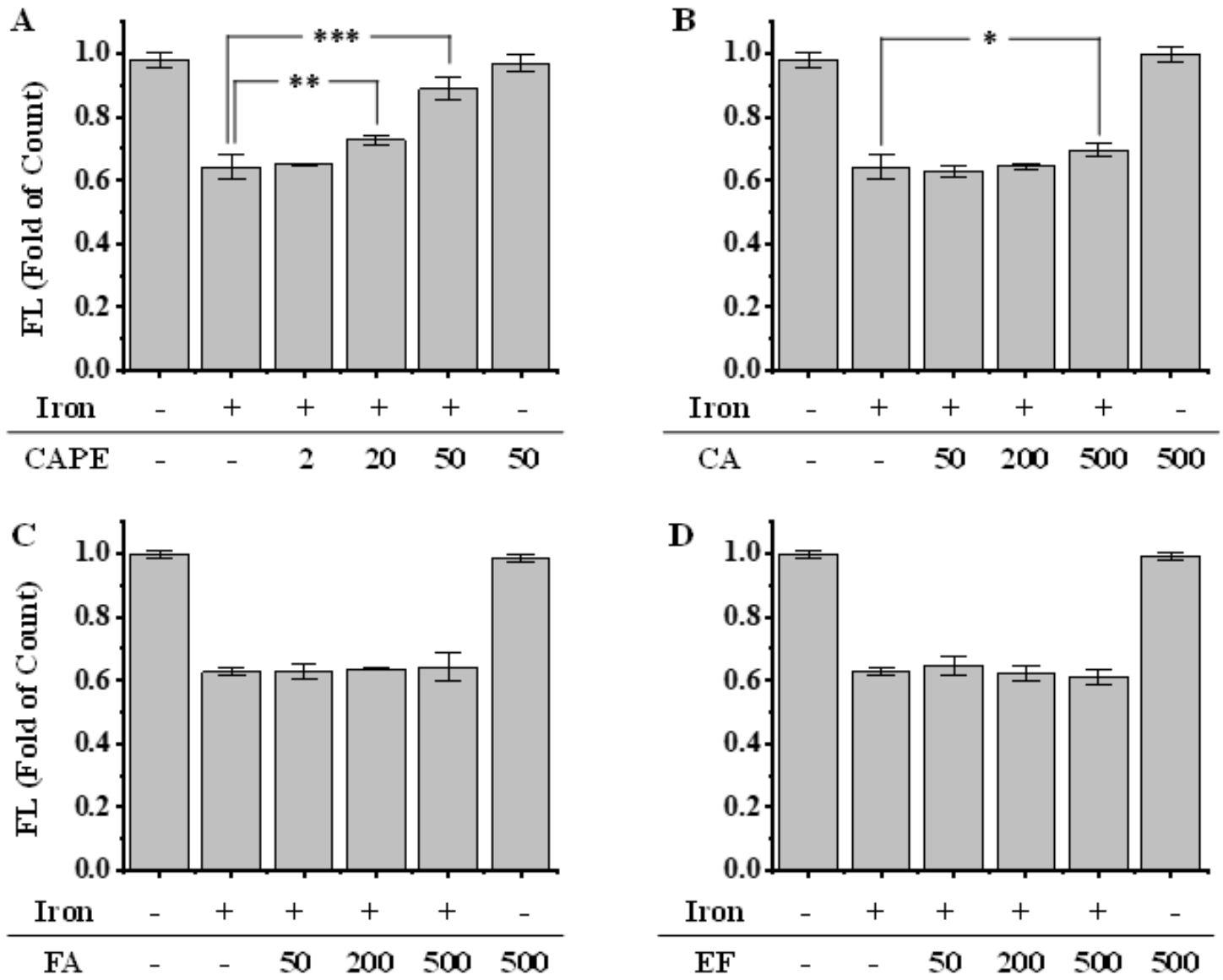

Figure 3. Effect of CAPE and its analogues on the LIP level in iron-overloaded cells, as measured by flow cytometry (A-D). HeLa cells were pretreated with $20 \mu \mathrm{M}$ Fe(II) for $2 \mathrm{~h}$ and then incubated with calcein-AM. After 15 min, cells were washed and incubated with or without CAPE and its analogues for $15 \mathrm{~min}$. The fluorescence intensity of cells was measured by flow cytometry. Significant differences from the iron-overloaded group are marked with ${ }^{*} p<0.05,{ }^{* *} p<0.01$, and ${ }^{* * *} p<0.001$. The experiment was repeated three times. 
Based on the results, we suggested that the inhibition of CAPE on oxidatively generated DNA damage was likely due to its ability to chelate overloaded iron and inhibit its redox activity. The catechol group of CAPE may play an important role in its iron-chelating ability. However, CA, which also has catechol group, exhibited a much weaker protective effect on iron-overloaded cellular DNA damage. This not only suggested that the protective effect depends on the ortho-dihydroxy group but also that the substituents at the para position of phenolic hydroxyl may play a critical role. To test the above hypothesis, we also employed two CAPE analogues, CAME and CAEE, to investigate their protective effect against iron overload-induced cellular DNA damage (Figure 1). As shown in Figure S3, 100-500 $\mu \mathrm{M}$ CAME or 50-500 $\mu \mathrm{M}$ CAEE could significantly inhibit iron overload-induced DNA damage, and their protective effect was found to be stronger than CA but weaker than CAPE. Similarly, we also found that 200-500 $\mu$ M CAME or 50-500 $\mu$ M CAEE could significantly regenerate the fluorescence of calcein (Figure S4), suggesting that CAME and CAEE (higher concentration) could also inhibit iron overload-induced DNA damage by decreasing LIP levels. Interestingly, although CAPE, CA, CAME, and CAEE have an orthodihydroxy group on their benzene rings, their protective effects were markedly different. These results confirmed that the protective effect may depend on the ortho-dihydroxy group, and the substituents at the para position of phenolic hydroxyl could also play a critical role. Based on the aforementioned considerations, we further investigated the protection of CAPE and its analogues against iron-mediated oxidative damage on isolated and purified DNA.

\subsection{CAPE Was Found to Be More Effective Than CA in Protecting Against Iron-Mediated DNA Damage as Measured by DNA Strand Breaks}

Plasmid DNA (pBR322) was employed to study whether CAPE and its analogues could protect against iron-mediated DNA strand breakage by $\bullet \mathrm{OH}$. Because of the facile hydrolysis of $\mathrm{Fe}(\mathrm{III})$ in an aqueous and neutral solution, an Fe(III)-citrate complex was used to study the protective effect of CAPE against DNA damage. Citrate anions are thought to be abundant in biological fluids, and Fe(III)-citrate has been considered as one of the major components of LIPs in cells [42,43]. As observed in Figure 4A, upon the addition of $\mathrm{Fe}(\mathrm{III})$-citrate/ascorbate $/ \mathrm{H}_{2} \mathrm{O}_{2}$, the supercoiled DNA decreased and converted into the relaxed circular and linear DNA. However, in the presence of CAPE, Fe(III)citrate/ascorbate $/ \mathrm{H}_{2} \mathrm{O}_{2}$-induced DNA strand breaks decreased significantly in a molar ratio (CAPE:Fe(III))-dependent manner. We found that DNA cleavage decreased with increasing ratios of CAPE:Fe(III); when the ratio increased over 2:1, the linear form of plasmid DNA completely disappeared and the supercoiled form markedly increased. Meanwhile, the protective effect of CA in this system was found to be lower than CAPE, while no significant protective effect was observed for FA or EF. As shown in Figure S5, CAPE also significantly inhibited $\mathrm{Fe}(\mathrm{II})-\mathrm{H}_{2} \mathrm{O}_{2}$-induced DNA strand breaks depending on the ratio. The protective activity of CAPE and its analogues decreased in the following order: $\mathrm{CAPE}>\mathrm{CA}>\mathrm{FA} \approx \mathrm{EF}$. This was similar to the trend of their protective activity against $\mathrm{Fe}(\mathrm{III})$-citrate/ascorbate $/ \mathrm{H}_{2} \mathrm{O}_{2}$-induced DNA damage.

These results indicated that CAPE and CA exhibit different protective effects against iron (Fe(II)/Fe(III))-mediated oxidatively generated DNA damage, and the protection of CAPE is stronger than CA. FA and EF exhibited no protective effect against iron-mediated DNA damage. 
A

C
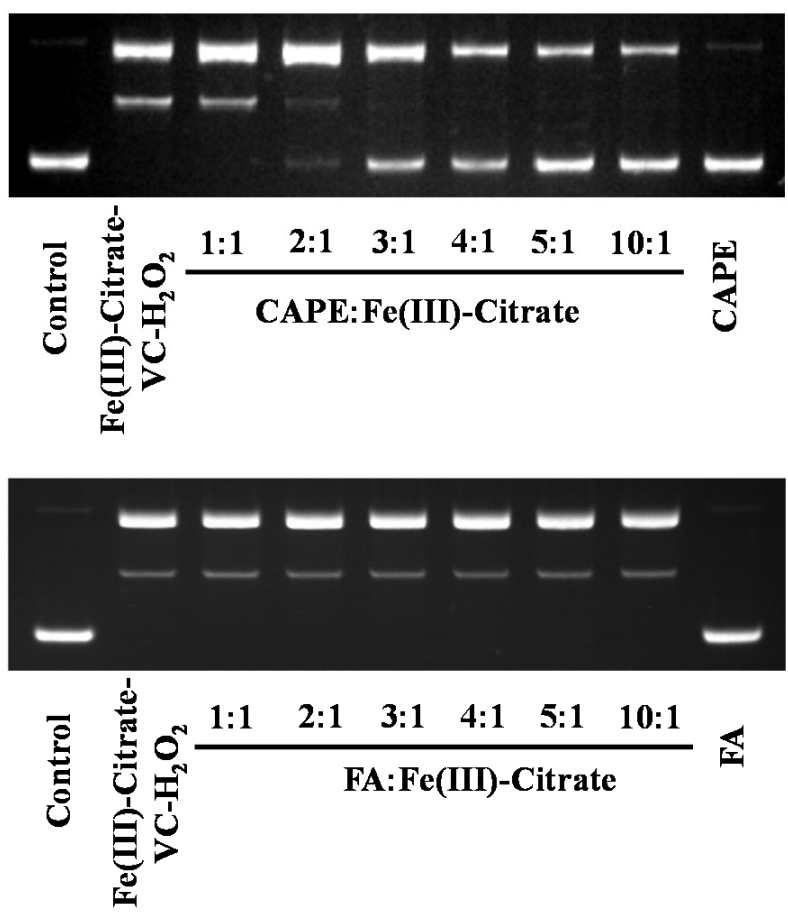

B
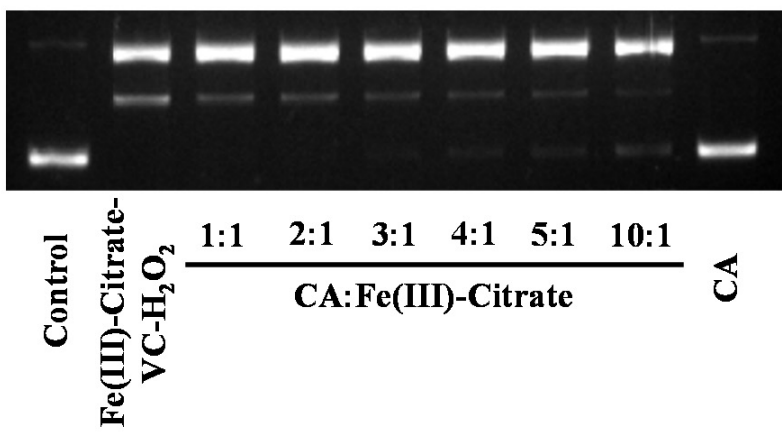

D
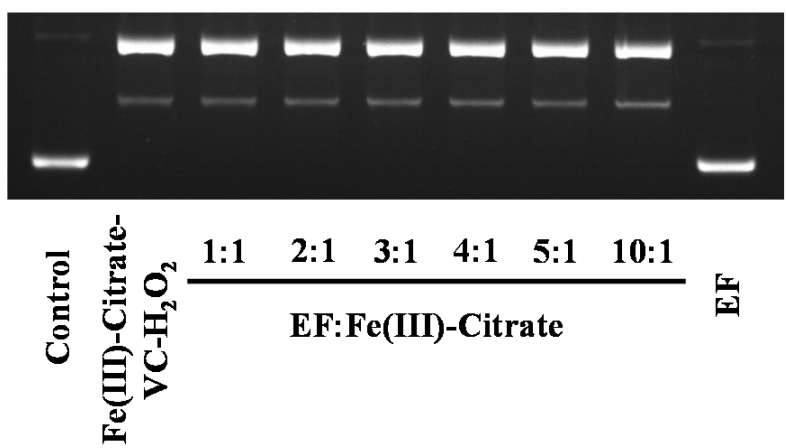

Figure 4. Protective effect of CAPE and its analogues against Fe(III)-citrate-ascorbate- $\mathrm{H}_{2} \mathrm{O}_{2}$-induced DNA damage. (A) 40-200 $\mu \mathrm{M}$ CAPE significantly inhibited Fe(III)-citrate- $-\mathrm{Vc}_{c}-\mathrm{H}_{2} \mathrm{O}_{2}$ induced DNA damage. (B) 20-200 $\mu \mathrm{M}$ CA slightly

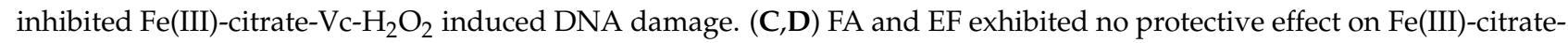
$\mathrm{Vc}-\mathrm{H}_{2} \mathrm{O}_{2}$ induced DNA damage. The reaction mixture contained $20 \mu \mathrm{M}$ Fe(III)-citrate, $10 \mu \mathrm{M}$ ascorbate, and $200 \mu \mathrm{M} \mathrm{H}_{2} \mathrm{O}_{2}$, as well as the indicated concentrations of CAPE and its analogues. The experiments were repeated three times, and only typical images are presented.

The ESR spin trapping method was also used to study the inhibition of CAPE and its analogues on the production of $\bullet \mathrm{OH}$ in an iron-mediated system. We found that $\mathrm{DMPO} / \bullet \mathrm{OH}$ and $\mathrm{DMPO} / \bullet \mathrm{CH}_{3}$ adducts could be produced by Fe(III)-citrate-ascorbate$\mathrm{H}_{2} \mathrm{O}_{2}$ in the presence of the spin-trapping agent DMPO and $\bullet \mathrm{OH}$ scavenger dimethyl sulfoxide (DMSO) (Figure S6), and the central part of the spectrum in Fe(III)-citrateascorbate system is ascorbyl radical $\left(\right.$ asc $\left.^{\bullet-}\right)$ [44]. As shown in Figure 5, DMPO/ $\bullet$ OH formation induced by an $\mathrm{Fe}(\mathrm{III})$ or $\mathrm{Fe}$ (II) system significantly decreased in the presence of CAPE or CA, though not with EF and FA. The inhibition of $\bullet \mathrm{OH}$ production by CAPE/CA was found to depend on the molar ratio of CAPE (CA): $\mathrm{Fe}(\mathrm{III}) /(\mathrm{Fe}(\mathrm{II}))$. The production of $\bullet \mathrm{OH}$ decreased with the increasing of the ratios. When the molar ratio of CAPE to $\mathrm{Fe}(\mathrm{III})$ increased to $2: 1$ or $\mathrm{CA}$ to $\mathrm{Fe}(\mathrm{III})$ increased to $10: 1, \bullet \mathrm{OH}$ production induced by $\mathrm{Fe}(\mathrm{III})$-citrate/ascorbate $/ \mathrm{H}_{2} \mathrm{O}_{2}$ was completely inhibited (Figure 5). In an $\mathrm{Fe}(\mathrm{II}) / \mathrm{H}_{2} \mathrm{O}_{2}$ system, CAPE also could completely inhibit $\bullet \mathrm{OH}$ production when the ratio of CAPE to $\mathrm{Fe}$ (II) increased to 3:1; however, even when the ratio of CA:Fe(II) increased to 20:1, significant $\bullet \mathrm{OH}$ production was still observed (Figure S8).

The above results indicated that CAPE and CA, but not EF and FA, could inhibit iron-mediated $\bullet \mathrm{OH}$ production in a ratio-dependent manner, which is similar with DNA damage inhibition results in vitro. We also found that CAME and CAEE could protect against iron-mediated DNA damage through inhibiting $\bullet \mathrm{OH}$ generation, but their protective effect was weaker than CAPE (Figures S9-S12). Therefore, we concluded that the ortho-dihydroxy group on the benzene rings of CAPE and CA plays an important role in iron-mediated DNA damage in vitro, indicating that they may chelate iron and affect its redox activity. 
A

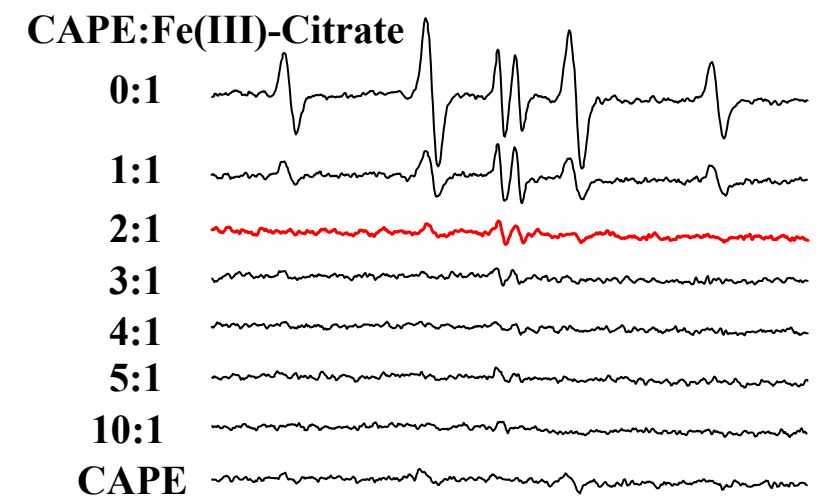

C

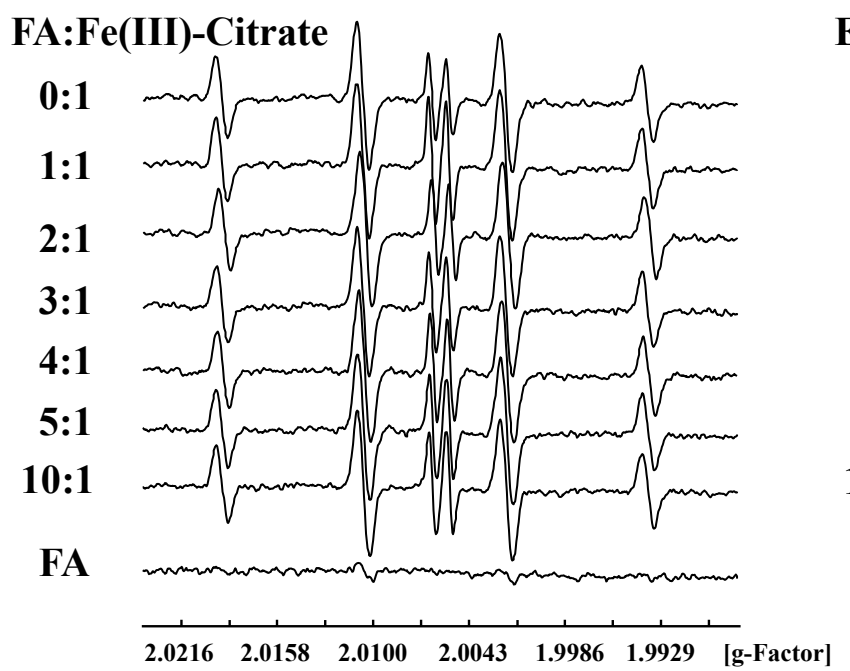

B

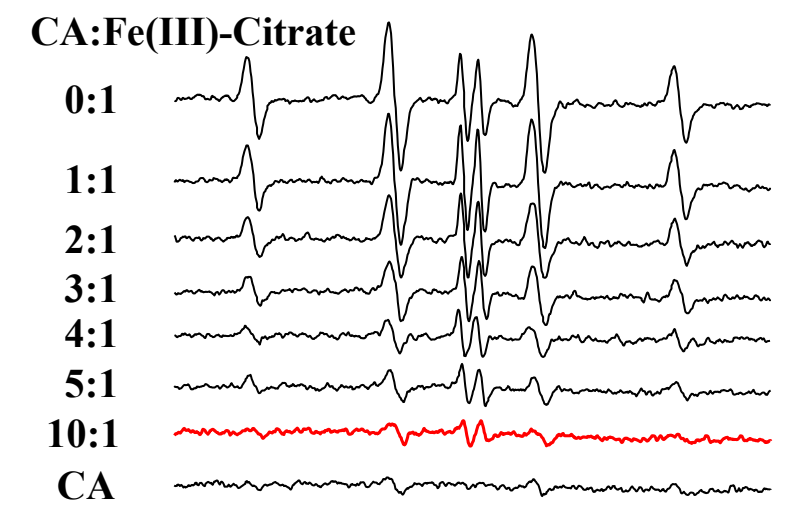

D

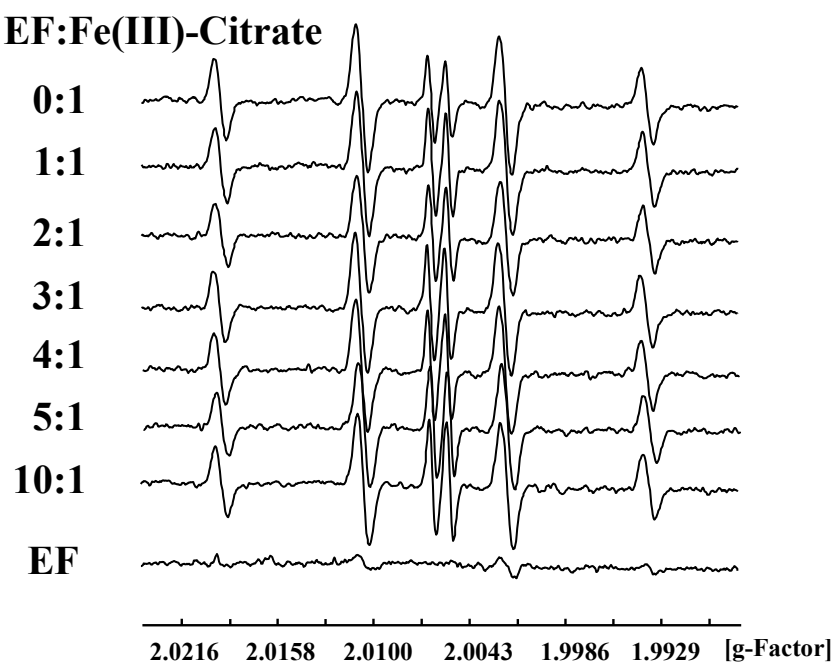

Figure 5. Inhibitory effect of CAPE and its analogues against $\mathrm{Fe}(\mathrm{III})-$ citrate- $-\mathrm{Vc}-\mathrm{H}_{2} \mathrm{O}_{2}$-induced $\bullet \mathrm{OH}$ generation. (A): $200 \mu \mathrm{M}$ CAPE completely inhibited $\mathrm{Fe}(\mathrm{III})$-citrate- $\mathrm{V}_{c}-\mathrm{H}_{2} \mathrm{O}_{2}$ induced $\bullet \mathrm{OH}$ generation. (B): 300-1000 $\mu$ M CA significantly inhibited $\mathrm{Fe}(\mathrm{III})$-citrate- $\mathrm{Vc}-\mathrm{H}_{2} \mathrm{O}_{2}$ induced $\bullet \mathrm{OH}$ generation. (C,D): FA and EF exhibited no inhibitory effect against Fe(III)-citrate-Vc$\mathrm{H}_{2} \mathrm{O}_{2}$ induced $\bullet \mathrm{OH}$ generation. The reaction mixture contained $100 \mu \mathrm{M}$ Fe(III)-citrate, $100 \mu \mathrm{M}$ ascorbate, and $1 \mathrm{mM} \mathrm{H}_{2} \mathrm{O}_{2}$, as well as the indicated concentrations of CAPE and its analogues. The experiments were repeated three times, and only typical spectra are presented.

However, the direct and systematic experimental evidence on the binding effect of CAPE/CA with iron is very limited so far. It is currently uncertain whether CAPE/CAiron complexes are formed; if so, what are the molar ratios of CAPE/CA-iron and their redox activity compared to iron alone? On the other hand, we found that the protective effect of CAPE and its analogues against DNA damage induced by an iron-containing system in vitro was different from that in HeLa cells: both CAPE and CA could protect against iron-mediated oxidative damage on isolated and purified DNA (plasmid DNA and ct-DNA), while only CAPE could markedly inhibit the cellular DNA damage induced by iron overload. The LIP analysis also indicated that only CAPE could diminish the fluorescence quenching induced by overloaded iron. Since both CAPE and CA have a catechol group and the ability to chelate iron, why did they show different protective effects in cellular DNA? In order to elucidate these questions, we further investigated the iron-chelating ability of CAPE and its analogues via different analytical methods such as UV-Vis, fluorescence, oxygen consumption, and FT-ICR-MS analysis. 


\subsection{CAPE Was Found to Have Strong Iron-Binding Ability, Leading to the Formation of Redox-Inactive Iron-CAPE Complex}

In Figure 6, the incremental addition of Fe(III)-citrate $(25-400 \mu \mathrm{M})$ to $100 \mu \mathrm{M} \mathrm{CAPE}$ gradually decreased the absorbance peak at $322 \mathrm{~nm}$, with concomitant increases at 350 and $570 \mathrm{~nm}$. Meanwhile, the UV-visible absorption spectra of CA and Fe(III) were similar to that of CAPE: after the addition of Fe(III)-citrate, new absorbance peaks at 372 and $610 \mathrm{~nm}$ appeared. These spectra changes suggested that both CAPE and CA could form CAPE/CA-iron complexes with iron, which have different characteristic absorption peaks than CAPE/CA alone. No significant new absorbance peak was observed in FA and EF with $\mathrm{Fe}(\mathrm{III})$-citrate, and the increase of the peaks of FA and EF could be attributed to the control group of Fe(III)-citrate alone, as shown in Figure S13. These spectral changes strongly suggested that the ortho phenolic hydroxy groups of CAPE or CA are essential for their iron coordination.

A

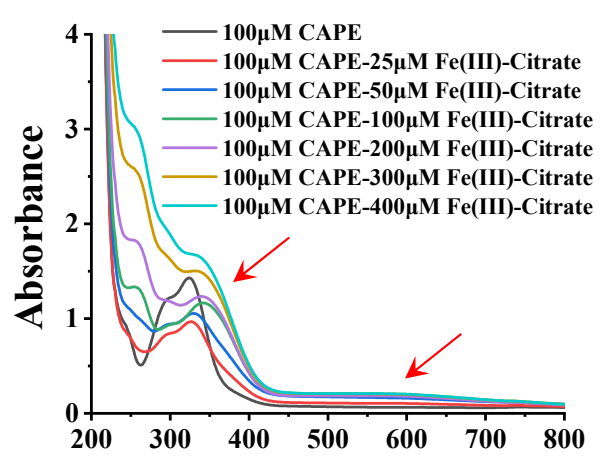

C

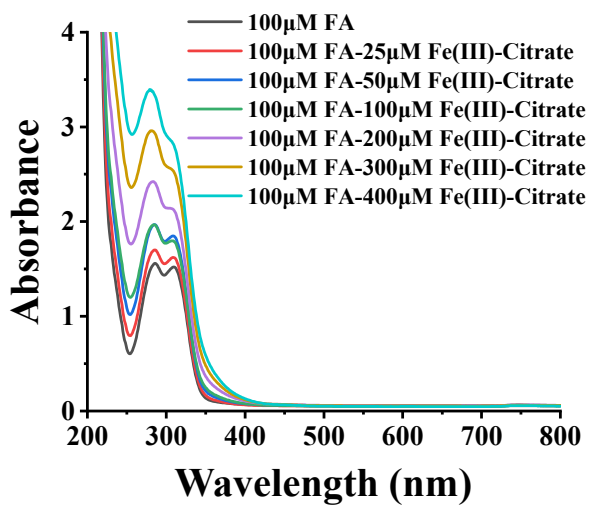

B

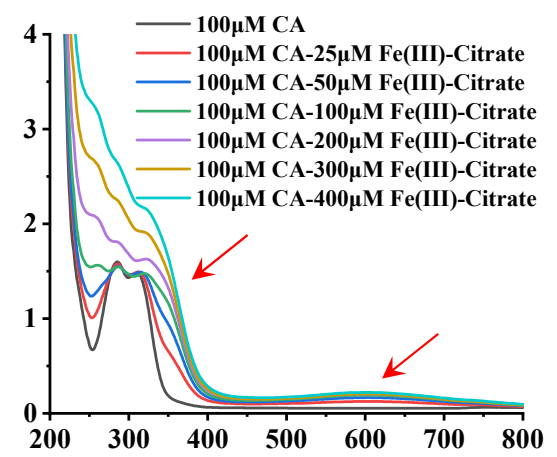

D

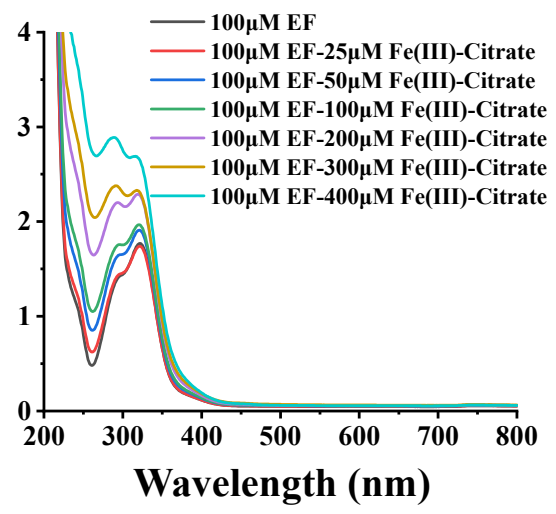

Figure 6. UV spectral changes observed upon the addition of Fe(III)-citrate to CAPE and its analogues. (A) the incremental addition of Fe(III)-citrate $(25-400 \mu \mathrm{M})$ to $100 \mu \mathrm{M}$ CAPE decreased the absorbance peak at $322 \mathrm{~nm}$, with concomitant increases at 350 and $570 \mathrm{~nm}$. (B) the incremental addition of Fe(III)citrate $(25-400 \mu \mathrm{M})$ to $100 \mu \mathrm{M}$ CAPE generated new absorbance peaks at 372 and $610 \mathrm{~nm}$. (C,D) No significant new absorbance peak was observed in FA and EF with Fe(III)-citrate. The reaction mixture contained $100 \mu \mathrm{M}$ CAPE or its analogues and different concentrations of Fe(III)-citrate $(25-400 \mu \mathrm{M})$. The experiments were repeated three times, and only typical spectra are presented.

The interactions of CAPE and its analogues with Fe(III)-citrate were further determined by the fluorescence method. The principle of the test is based on the binding of calcein to iron in a stoichiometric manner, which results in a fluorescence quenching. Therefore, a lower reading in fluorescence intensity indicates a higher level of iron in biological fluids $[45,46]$. The affinity constants for calcein are $10^{14}$ and $10^{24} \mathrm{M}^{-1}$ for $\mathrm{Fe}(\mathrm{II})$ and $\mathrm{Fe}$ (III), respectively [47]. Furthermore, calcein acetoxymethyl ester (calcein-AM) can also be used to estimate LIP in cells due to the high cell membrane permeability of calcein-AM [48-50]. 
The quenching effect of iron on calcein fluorescence was examined by measuring the changes in the fluorescence intensity of calcein after mixing iron $(100 \mu \mathrm{M})$ with calcein $(1 \mu \mathrm{M})$ in a $20 \mathrm{mM}$ HEPES buffer at $\mathrm{pH}$ 7.4. As shown in Figure 7, the fluorescence of $0.1 \mu \mathrm{M}$ calcein was significantly quenched by $100 \mu \mathrm{M}$ Fe(III)-citrate, which could be attributed to the binding between calcein and $\mathrm{Fe}(\mathrm{III})$. However, after the addition of CAPE, the fluorescence quenching by $\mathrm{Fe}(\mathrm{III})$-citrate gradually diminished in a (CAPE:Fe(III)) ratiodependent manner, and when the ratio increased to over 3:1, the fluorescence quenching was completely abolished by CAPE. CAPE alone could neither quench nor enhance the calcein fluorescence intensity. However, CA showed a weaker inhibition of fluorescence quenching by $\mathrm{Fe}(\mathrm{III})$-citrate, even when the ratio increased to 5:1. FA and EF showed no inhibitory effects. The analogous inhibitory effect of CAPE and its analogues on the fluorescence quenching by $\mathrm{Fe}(\mathrm{II})$ can also be observed in Figure S14: CAPE significantly diminished the fluorescence quenching when the ratio increased to $4: 1$. The inhibitory effect of CAPE on fluorescence quenching by $\mathrm{Fe}$ (III)-citrate or Fe(II) resulted from competitive iron binding with CAPE and calcein. However, CA exhibited a weaker inhibitory effect on fluorescence quenching by iron, which had a similar chemical structure to CAPE. This result indicated that the affinity of CA to iron is weaker than CAPE.

A

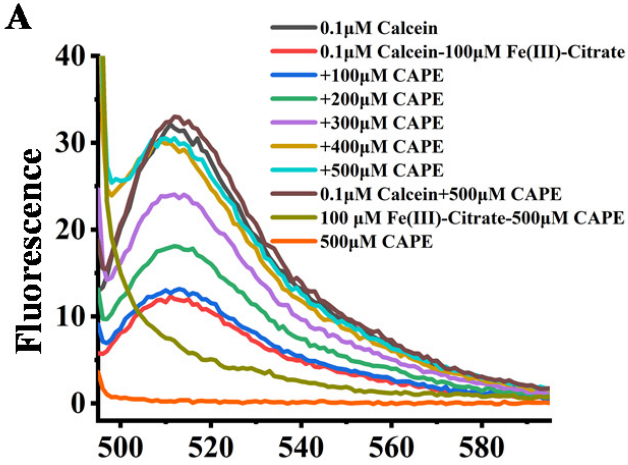

C

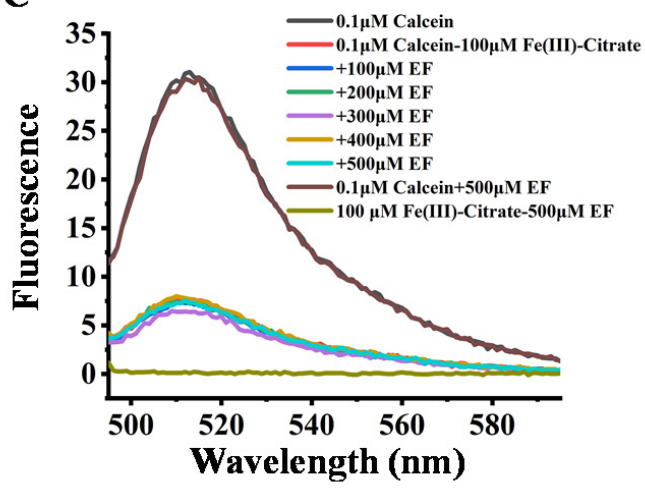

B

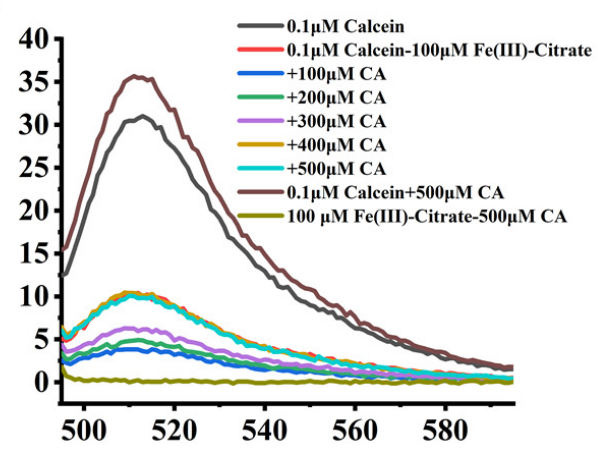

D

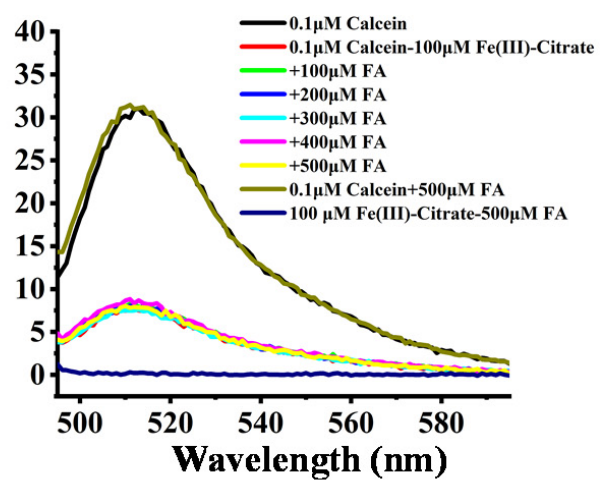

Figure 7. Effect of CAPE and its analogues on the fluorescence intensity of calcein-Fe(III)-citrate. $(\mathbf{A}, \mathbf{B})$ the fluorescence quenching of calcein by $\mathrm{Fe}(\mathrm{III})$-citrate diminished in a (CAPE/CA:Fe(III)) ratio-dependent manner. (C,D) EF and FA exhibited no inhibition of fluorescence quenching by $\mathrm{Fe}(\mathrm{III})$-citrate. The reaction mixture contained $0.1 \mu \mathrm{M}$ calcein, $100 \mu \mathrm{M}$ Fe(III)-citrate, and indicated concentrations of CAPE or its analogues $(100-500 \mu \mathrm{M})$. The experiments were repeated three times, and only typical spectra are presented.

Dissolved oxygen consumption was also used to investigate the redox activity of CAPE/CA-iron complexes. We found that the redox reaction between ascorbic acid and $\mathrm{Fe}(\mathrm{III})$-citrate induced significant oxygen consumption and that CAPE significantly decreased oxygen consumption as the ratio of CAPE:Fe(III) increased (from approximately 1:1 to 3:1), suggesting that CAPE may bind with Fe(III) to form a redox-inactive (less reactive) CAPE-Fe(III) complex, as compared with Fe(III)-citrate (Figure S15A). It can be 
seen in Figure S15B that only when the ratio of CA to Fe(III) increased to 5:1 could a decrease of $\mathrm{O}_{2}$ consumption be observed. EF and FA had no significant effects on the $\mathrm{O}_{2}$ consumption induced by ascorbic acid/Fe(III)-citrate (Figure S15C,D).

We also detected the change of redox potential of Fe(III) after being chelated by CAPE or CA through cyclic voltammetry methods. Figure S16 shows that Fe(III) alone exhibited its reduction peak at approximately $-0.65 \mathrm{~V}$. When Fe(III) was chelated by CAPE, the reduction potential decreased to $-1.00 \mathrm{~V}$, indicating that the chelation of CAPE to $\mathrm{Fe}(\mathrm{III})$ significantly inhibited the redox activity of Fe(III). Similarly, the chelation of CA, CAME, and CAEE decreased the reduction potential of Fe(III) to $-0.76,-0.79$, and $-0.99 \mathrm{~V}$, respectively, which suggested that all four chelators could inhibit the redox activity of $\mathrm{Fe}(\mathrm{III})$ through their chelating effects, as well as that the inhibitory effect of CAPE is stronger than CA. These results were consistent with the optical spectral analyses and dissolved oxygen consumption experiments, which further confirmed that the inhibition of both - OH generation and DNA damage by CAPE or CA in an iron-containing system is due to formation of redox-inactive (or less reactive) iron complexes.

It should be also interesting to know the exact molar ratio of CAPE with $\mathrm{Fe}(\mathrm{III}) / \mathrm{Fe}(\mathrm{II})$. As shown in Figure 8, in the reaction solution involved CAPE and Fe(III), the quasimolecular ion of the compounds with $\mathrm{m} / \mathrm{z}$ values of 622.12728 and 906.23047 , respectively, were detected by FT-ICR-MS in the positive ion mode. Following a comparison of the molecular weights and isotopic distributions, the molecular formula of the compounds with $\mathrm{m} / \mathrm{z}$ at 622.12728 and 906.23047 were assumed to be $\mathrm{C}_{34} \mathrm{H}_{30} \mathrm{O}_{8} \mathrm{Fe}$ and $\mathrm{C}_{51} \mathrm{H}_{46} \mathrm{O}_{12} \mathrm{Fe}$, respectively, which could be proposed to be the $\mathrm{M}^{+}$or $[\mathrm{M}+\mathrm{H}]^{+}$of the CAPE/Fe(III) complexes formed by 2:1 and 3:1 ratios, respectively. In Figure 9, the molecular formula of the compounds at 414.00305 and 594.04448 were assumed to be $\mathrm{C}_{18} \mathrm{H}_{14} \mathrm{O}_{8} \mathrm{Fe}$ and $\mathrm{C}_{27} \mathrm{H}_{22} \mathrm{O}_{12} \mathrm{Fe}$, respectively, which could be assigned as the $\mathrm{CA} / \mathrm{Fe}$ (III) complexes formed by 2:1 and 3:1 ratios, respectively. These results provided more convincing evidence for the formation of CAPE/CA-iron complexes with molar ratios of 2:1 or 3:1, respectively. Moreover, we measured the competitive binding effect between CAPE and CA with iron. We found that the mixture containing equivalent $\mathrm{CAPE}$ and CA preferentially formed CAPE-iron complexes over CA-iron complexes, which also suggested that the iron-cheating ability of CAPE is stronger than CA (Figure 10).
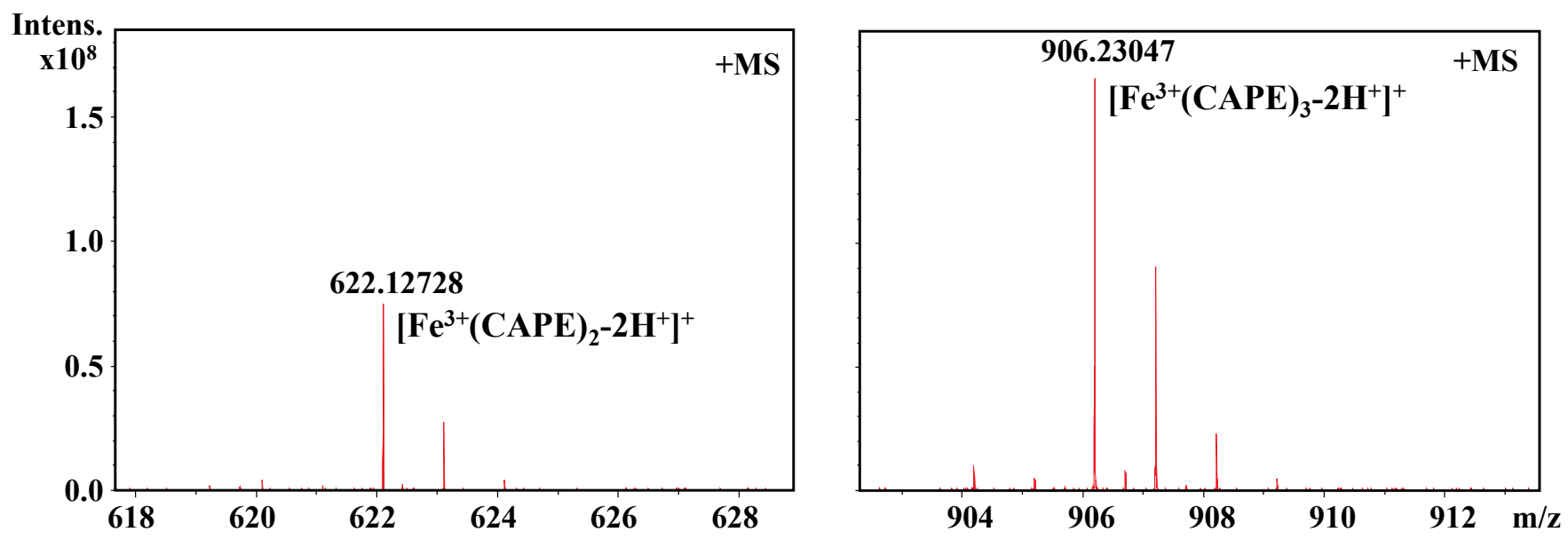

Figure 8. Formation of a CAPE-Fe(III) complex as characterized by FT-ICR-MS analysis. The reaction mixture contained $100 \mu \mathrm{M}$ CAPE and $10 \mu \mathrm{M}$ Fe(III) in a $20 \mathrm{mM}$ ammonium acetate buffer (pH 7.4). 

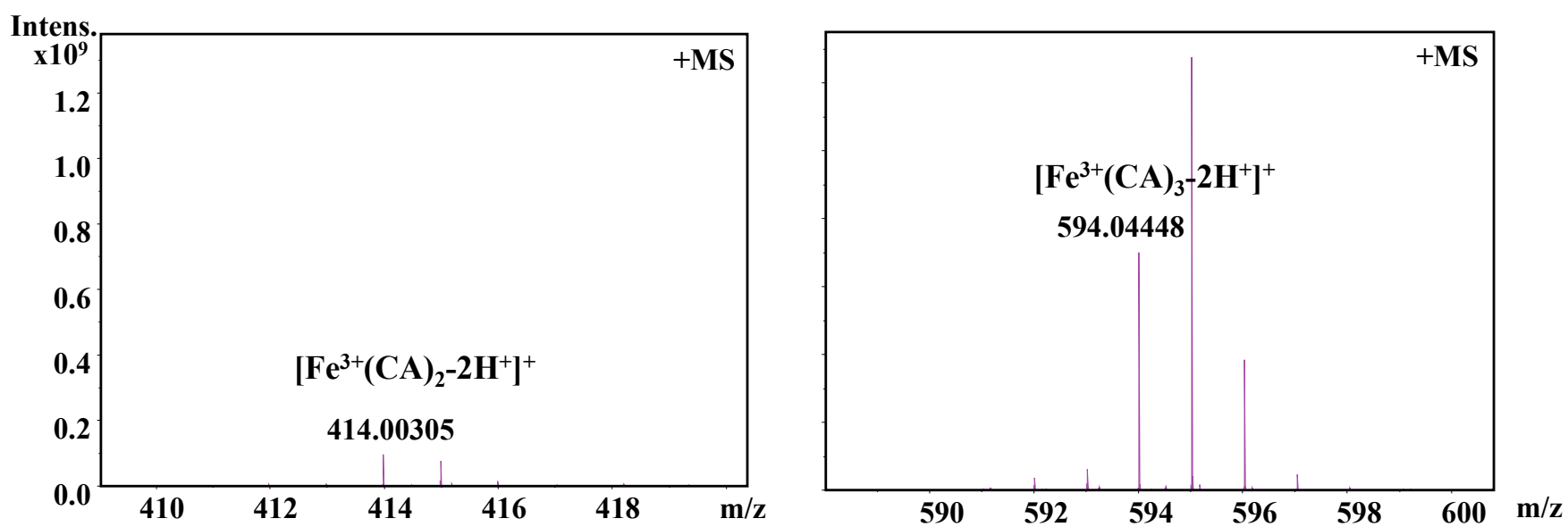

Figure 9. Formation of a CA-Fe(III) complex as characterized by FT-ICR-MS analysis. The reaction mixture contained $100 \mu \mathrm{M}$ CA and $10 \mu \mathrm{M}$ Fe(III) in a $20 \mathrm{mM}$ ammonium acetate buffer (pH 7.4).

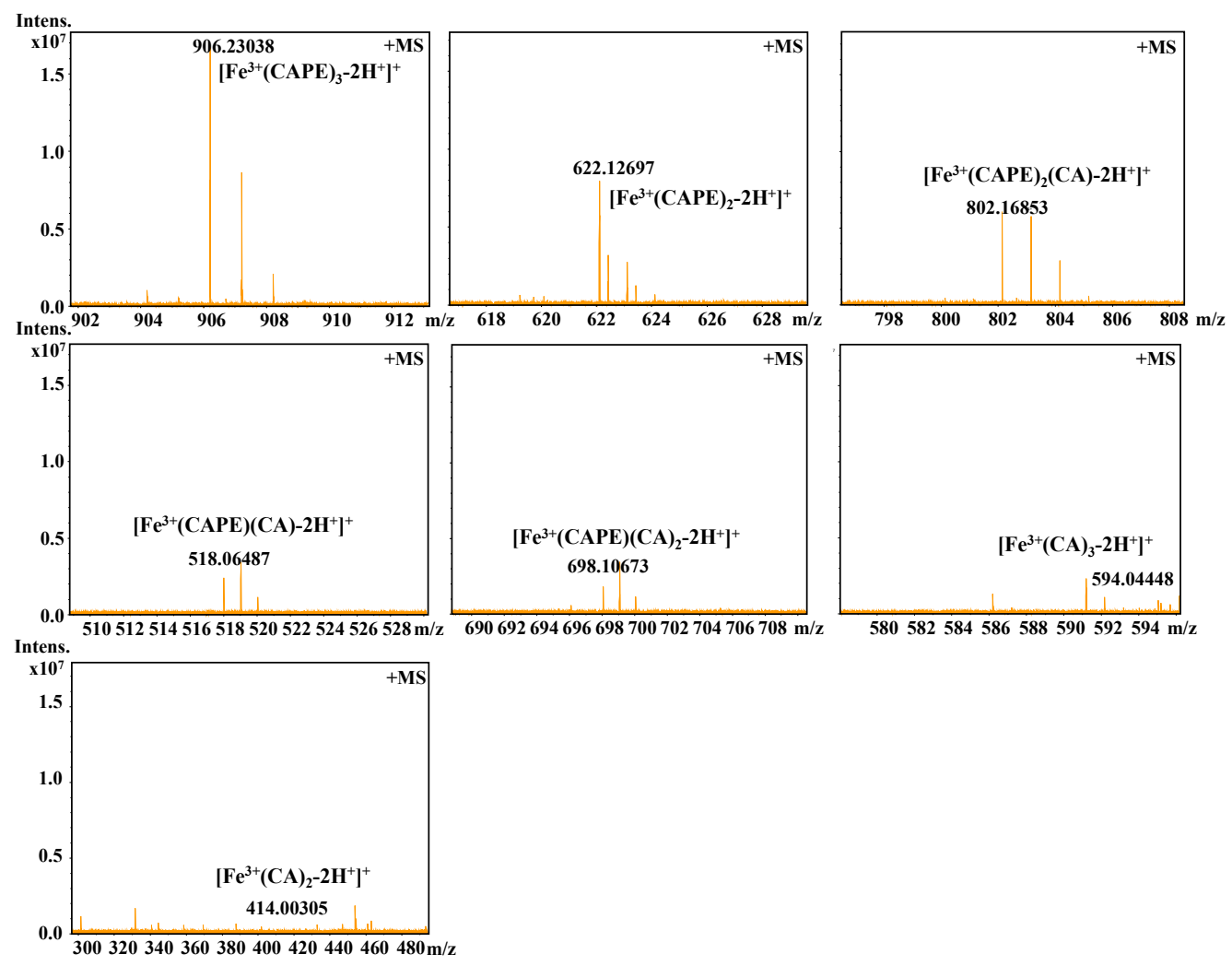

Figure 10. Competitive binding of Fe(III) by CAPE and CA, as characterized by FT-ICR-MS analysis. The reaction mixture contained $100 \mu \mathrm{M} \mathrm{CAPE}, 100 \mu \mathrm{M} \mathrm{CA}$, and $10 \mu \mathrm{M} \mathrm{Fe}(\mathrm{III})$ in a $20 \mathrm{mM}$ ammonium acetate buffer ( $\mathrm{pH} 7.4)$.

We further determined their stoichiometry by job's titration. As shown in Figure S17, the ligands including CAPE, CA, CAME, and CAEE were able to chelate iron at two different molar ratios (2:1 and 3:1 for ligands and iron, respectively). We also investigated their binding constants through titration methods. The binding constants $\left(\mathrm{K}_{\mathrm{b} \text { (iron-ligands) }}\right)$ between iron and CAPE/CA/CAME/CAEE were studied by the fluorescence displacement method (Table S1; for details, see the Materials and Methods section). In this study, only CAPE was found to be able to effectively compete with calcein to bind iron, while CA/CAME/CAEE exhibited no such competitive effect. The binding constants between each ligand and Fe(III) were calculated with the equation shown in Material and Methods. 
We found that the $\mathrm{K}_{\mathrm{b}(\mathrm{Fe}(\mathrm{III})-\mathrm{CAPE})}$ was approximately $0.63 \times 10^{22} \mathrm{M}^{-1}$, while the $\mathrm{K}_{\mathrm{b}}$ values of $\mathrm{Fe}(\mathrm{III})$ with other three ligands (CA, CAME, and CAEE) were less than $10^{20} \mathrm{M}^{-1}$ (Table S1).

We first systematically studied the interaction of CAPE and its analogues with iron $(\mathrm{Fe}(\mathrm{III}) / \mathrm{Fe}(\mathrm{II}))$, providing more direct and stronger experimental evidence for the formation of inactive (or less reactive) CAPE/CA-Fe(III)/Fe(II) complexes, which have important biological significance for future study on polyphenol-related antioxidant effects.

From the above results, we found that the iron-chelating ability of CAPE is significantly stronger than CA. We speculated that the difference of iron-binding affinity between CAPE and CA may have been due to the following reasons: Compared with carboxylate, phenethyl is a significant electron-donating group [51,52], and the binding constants of metals to ligands increase with the increasing electron-donating ability of the parasubstituent [53-55]. Therefore, the high iron-binding affinity by CAPE may have a close relationship with the esterification of the carboxylic moiety with phenethyl, which could enhance the electronic density over the oxygen atom and increase its chelating ability. On the other hand, hard-hard or soft-soft combinations are kinetically favored [52]. Within a stronger electron-donor power, CAPE has a lower electron affinity and a higher molecular hardness; accordingly, the Fe(III)-binding constant of CAPE is the largest among the four analogues [52]. Similarly, when the hydrogen atom in the -COOH group was substituted with a methyl or ethyl group, which were also electron-donating groups, its iron-chelating ability was also found to increase [52]. Therefore, the stronger iron-chelating ability of CAPE and redox-inactive CAPE-iron complex formation should be the key factor for its more potent protective effect against iron-overload-mediated cellular DNA damage.

However, although CA is a weaker chelator with iron, it still could protect ironmediated DNA damage in purified DNA, which is not consistent with its protective effect in cellular DNA in cells. We speculate that this may be related to the different lipophilicity values of CA and CAPE.

\subsection{High Lipophilicity of CAPE Enhanced Its Protective Effect Against Iron-Mediated Cellular DNA Damage}

According to previous studies, the lipophilic character of antioxidants is an important factor in their biological activity [56-59]. Though various polyphenol compounds, which can be found in natural products, have been shown to be excellent antioxidants [60-63], the lipophilic nature of biological membranes restricts the direct intracellular delivery of many hydrophilic antioxidants that cannot cross the cell membrane and exhibit their antioxidant activities inside a cell [64]. Therefore, in this study, besides the difference of the iron-chelating ability between CAPE and CA, the different lipophilicity values of CAPE and CA may have been other important reasons for their protective effect against cellular DNA damage induced by iron, thus allowing these compounds to cross the cell membrane and chelate excessive cellular iron, which may be modulated by their hydrophobic or hydrophilic groups.

As shown in Table 1, the $\operatorname{LogK}_{\text {ow }}$ value of CAPE $(2.01 \pm 0.02)$ was found to be much higher than those of CA $(-0.98 \pm 0.02)$, CAME $(1.27 \pm 0.06)$, and CAEE $(1.51 \pm 0.03)$ (Table 1), which suggested that the esterification of the carboxylic moiety with phenethyl significantly decreases polarity and strongly increased lipophilicity. The lipophilicity of CAPE could facilitate its transport across the cell membrane, where it could exhibit its iron-chelating ability inside the cell [65]. Compared with CAPE, we also found that CA, CAME, and CAEE showed weaker effects on the LIP levels and cellular DNA damage induced by iron. Therefore, although all of them have ortho phenolic hydroxy groups, their lipophilicities are different. Only CAPE could be able to effectively cross the cell membrane and protect against iron-mediated cellular DNA damage through its iron-chelating ability, which can be attributed to the phenethyl esterification of CAPE and its highest lipophilicity among them. Interestingly, since both CAPE and CA have auto-fluorescence (Ex: 330 nm; Em: $\sim 450 \mathrm{~nm}$ ), we found that the incubation of CAPE with cells could significantly increase its fluorescence inside the cells. However, no significant increase was observed in the CA group (Figure S18), which confirmed that it is indeed much easier for CAPE to cross 
the cell membrane than CA. These results provided good evidence supporting the strong protective effect of CAPE, but not CA, against iron overload-induced cellular DNA damage (Scheme 1).

Table 1. The $\log _{\mathrm{ow}}$ values of CAPE and its analogues.

\begin{tabular}{cc}
\hline Compounds & LogKow \\
\hline CAPE & $2.01 \pm 0.02$ \\
CA & $-0.98 \pm 0.02$ \\
CAME & $1.27 \pm 0.06$ \\
CAEE & $1.51 \pm 0.03$ \\
EF & $1.38 \pm 0.02$ \\
FA & $-0.77 \pm 0.01$ \\
\hline
\end{tabular}

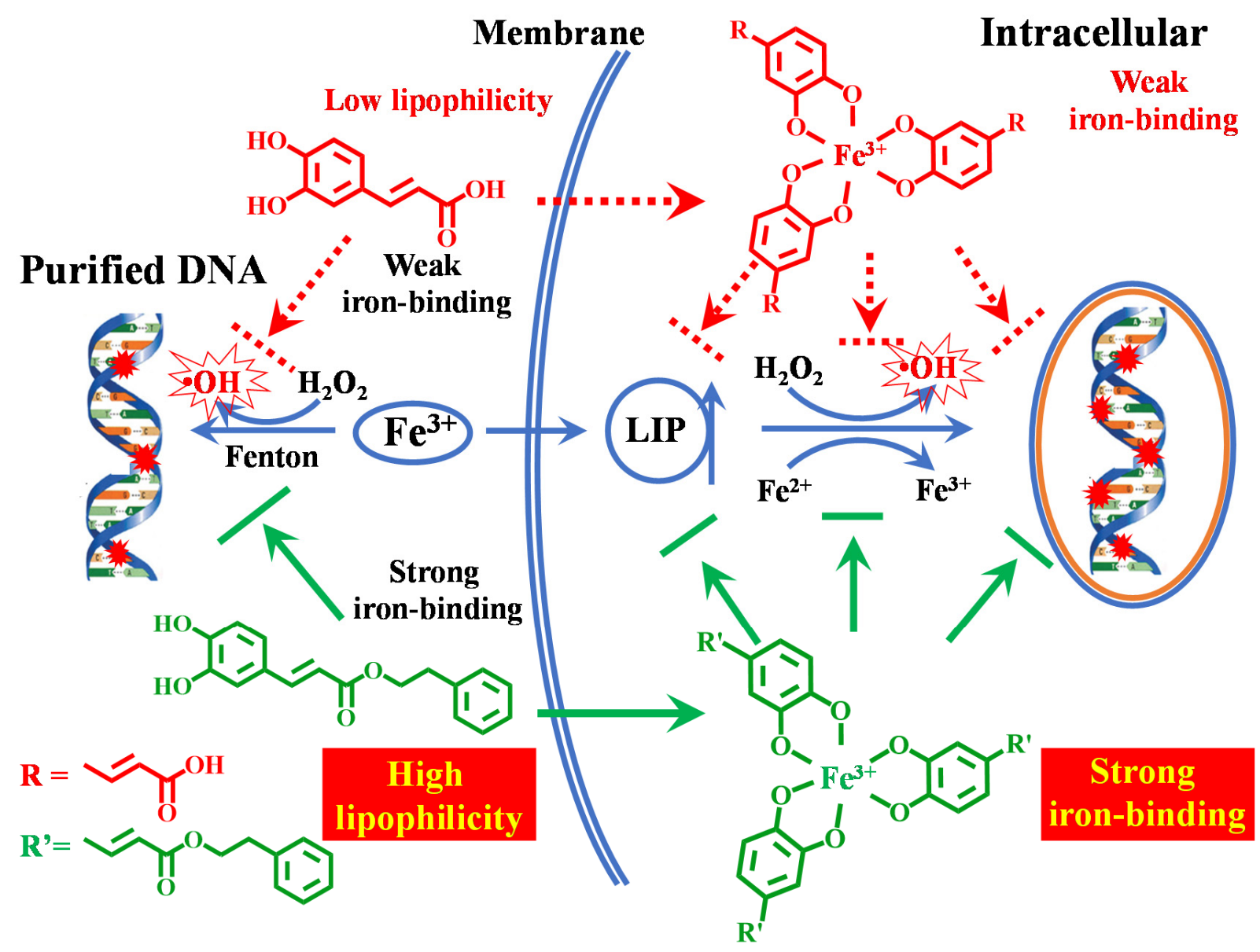

Scheme 1. Proposed mechanism of protection by caffeic acid phenyl ester (CAPE) against iron-mediated cellular DNA damage.

In summary, the protective effect of CAPE against DNA damage induced by iron in cells depends not only on its strong iron-binding activity but also on its high lipophilicity. It is noteworthy that both the ortho phenolic hydroxy groups and the substituent at the para position of phenolic hydroxyl have close relationships with the iron-chelating ability and lipophilicity of the phenolic compounds, which are very critical for their protective effect.

3.6. Iron-Chelating Ability of CAPE, but Not Its Radical Scavenging Ability, Is Responsible for Its Protection Against Iron-Mediated DNA Damage

The antioxidant properties of natural antioxidants, especially polyphenol compounds, are generally achieved in two pathways: (1) directly scavenging free radicals and (2) chelating transition metals, especially iron, that may inhibit the formation of free radicals $[66,67]$. 
It is generally believed that several functional groups of polyphenol compounds are essential for iron chelation: (a) the presence of ortho-dihydroxy groups, (b) the combination of 5-OH and/or 3-OH with a $\mathrm{C} 4$ keto group, and (c) a large number of $\mathrm{OH}$ groups [68]. Among them, it has been reported that two hydroxy groups in the ortho-position play key roles in the iron chelation and protection of phenolic compounds $[26,69,70]$. Therefore, in this study, since polyphenols such as CAPE and CA possess ideal structural features for iron chelation, it is reasonable to speculate that the protective effects exerted by CAPE/CA, but not $\mathrm{EF}$ and FA, might be due to their iron-chelating activity. As mentioned above, we showed that CAPE could protect against iron-mediated cellular DNA damage by decreasing LIP levels, which supports the important role of the iron-chelating ability of CAPE. Furthermore, we found that the typical lipophilic iron chelator 1,10-phenanthroline (OP) [26,69-72], but not its hydrophilic analogue bathophenanthroline disulfonate (BPS) (which exhibited no free radical scavenging activities), is also effective in preventing ironmediated cellular DNA damage through lowing LIP levels (Figures S19-S21). Previous studies have also suggested that both FA and EF have free radical scavenging activities [65], but they exhibited no protective effect against iron-mediated DNA damage in this study. On the other hand, CAPE may hydrolyze to release alcohol, particularly in cells, which might play a critical role in the protective effect through scavenging free radicals. However, as shown in Figure S1, EF exhibited no protective effect on cellular DNA damage, even if it could hydrolyze to release alcohol. Therefore, the contribution of ester hydrolysis to the protective effect in cells can be ruled out. Taken together, our results suggested that the most prominent activity of CAPE in the protection against iron-mediated DNA damage is its strong ability to chelate iron.

\subsection{Potential Biological Implications}

Iron overload has been shown to cause several adverse effects in many biological systems, such as ischemia reperfusion injury, neurodegenerative diseases, and inflammation [1,4-6]. Current studies are seeking exogenous ligands to chelate excess iron and to maintain the oxidative balance of cells and tissues. Chelating agents can play a therapeutic role by restricting iron from participating in free radical generation. At the same time, ironchelating agents can also be used in the development of anti-tumor drugs by consuming excess iron or causing selective oxidative stress in tumor cells [73,74]. For the purpose of exerting their pharmacological effects, the chelating agents must not only have a strong iron affinity but also be able to cross biological membranes to reach the target site and exert their pharmacological effects [75].

In this study, both the strong iron-binding ability and high lipophilicity (which have close relationship with the ortho phenolic dihydroxy group and the substituent at the para position of phenolic hydroxyl, respectively) make CAPE—but not CA, EF, and FA—be the major biologically active principles in propolis. The strong iron-chelating ability of CAPE in cells may also make it be a potent anti-tumor agent, which could limit tumor growth by depleting iron. This study provided a novel insight into the development of more potent iron chelators and the antioxidant mechanism of natural phenolic compounds.

\section{Conclusions}

This study proposed that the esterification of the carboxylic moiety with phenethyl significantly enhanced the iron-binding ability and lipophilicity of CAPE, which is also responsible for its potent protection against iron-mediated cellular DNA damage. A study on the iron coordination mechanism of such natural polyphenol antioxidants will help to design more effective antioxidants for the treatment and prevention of diseases caused by metal-induced oxidative stress, as well as help to understand the structure-activity relationships of these compounds. 
Supplementary Materials: The following are available online at https: / www.mdpi.com/article / 10.3390/antiox10050798/s1.

Author Contributions: Conceptualization, B.S., L.M., and B.-Z.Z.; data curation, B.S. and L.M.; formal analysis, L.M., M.T., Z.-Y.Y., J.S., C.-H.H., and Z.-G.S.; funding acquisition, B.S., L.M., C.-H.H., Z.-G.S., and B.-Z.Z.; investigation, L.M. and B.-Z.Z.; writing-original draft, B.S., L.M., and B.-Z.Z. All authors have read and agreed to the published version of the manuscript.

Funding: This work was supported by "From 0 to 1" Original Innovation Project, the Basic Frontier Scientific Research Program, CAS (ZDBS-LY-SLH027); NSF China Grants (21836005, 22021003, 92043301, 21777180, 21577149, 21621064, 21377158, 21976199, 22006050); NSFC cultivation project of Jining Medical University [JYP201726]; Research Support Foundation of Jining Medical University [JYFC2018KJ061]; State Key Laboratory of Environmental Chemistry and Ecotoxicology, Research Center for Eco-Environmental Sciences, Chinese Academy of Sciences [KF2020-18].

Institutional Review Board Statement: Not applicable.

Informed Consent Statement: Not applicable.

Data Availability Statement: Not applicable.

Conflicts of Interest: The authors declare no conflict of interest.

\section{References}

1. Fonseca-Nunes, A.; Jakszyn, P.; Agudo, A. Iron and Cancer Risk-A Systematic Review and Meta-analysis of the Epidemiological Evidence. Cancer Epidemiol. Biomark. Prev. 2014, 23, 12-31. [CrossRef]

2. Zhao, B.L.; Yang, Y.; Wang, X.L.; Chong, Z.C.; Yin, R.C.; Song, S.H.; Zhao, C.; Li, C.P.; Huang, H.; Sun, B.F.; et al. Redox-active quinones induces genome-wide DNA methylation changes by an iron-mediated and Tet-dependent mechanism. Nucleic Acids Res. 2014, 42, 1593-1605. [CrossRef] [PubMed]

3. Zhu, B.Z.; Frei, B. Biochemical and physiological interactions of vitamin C and iron: Pro- or antioxidant? In The Antioxidant Vitamins $C$ and E; Packer, L., Traber, M.G., Kraemer, K., Frei, B., Eds.; Amer Oil Chemists Soc: Champaign, IL, USA, 2002; pp. 32-49.

4. Zucca, F.A.; Segura-Aguilar, J.; Ferrari, E.; Munoz, P.; Paris, I.; Sulzer, D.; Sarna, T.; Casella, L.; Zecca, L. Interactions of iron, dopamine and neuromelanin pathways in brain aging and Parkinson's disease. Prog. Neurobiol. 2017, 155, 96-119. [CrossRef] [PubMed]

5. Belaidi, A.A.; Bush, A.I. Iron neurochemistry in Alzheimer's disease and Parkinson's disease: Targets for therapeutics. J. Neurochem. 2016, 139, 179-197. [CrossRef] [PubMed]

6. von Haehling, S.; Jankowska, E.A.; van Veldhuisen, D.J.; Ponikowski, P.; Anker, S.D. Iron deficiency and cardiovascular disease. Nat. Rev. Cardiol. 2015, 12, 659-669. [CrossRef] [PubMed]

7. Doulias, P.T.; Nousis, L.; Zhu, B.Z.; Frei, B.; Galaris, D. Protection by tropolones against H2O2-induced DNA damage and apoptosis in cultured Jurkat cells. Free Radic. Res. 2005, 39, 125-135. [CrossRef]

8. Barbouti, A.; Doulias, P.T.; Zhu, B.Z.; Frei, B.; Galaris, D. Intracellular iron, but not copper, plays a critical role in hydrogen peroxide-induced DNA damage. Free Radic. Biol. Med. 2001, 31, 490-498. [CrossRef]

9. Galaris, D.; Zhu, B.Z.; Frei, B. On the role of iron and copper ions in hydrogen peroxide-induced cellular DNA damage. Free Radic. Biol. Med. 2002, 32, 198-199. [CrossRef]

10. Suh, J.; Zhu, B.Z.; Frei, B. Ascorbate does not act as a pro-oxidant towards lipids and proteins in human plasma exposed to redox-active transition metal ions and hydrogen peroxide. Free Radic. Biol. Med. 2003, 34, 1306-1314. [CrossRef]

11. Levy, S.; Shechtman, S.; Zhu, B.Z.; Stadtman, E.R.; Stadler, R.; Chevion, M. Synergism between the toxicity of chlorophenols and iron complexes. Environ. Toxicol. Chem. 2007, 26, 218-224. [CrossRef]

12. Qu, N.; Guo, L.H.; Zhu, B.Z. An electrochemical biosensor for the detection of tyrosine oxidation induced by Fenton reaction. Biosens. Bioelectron. 2011, 26, 2292-2296. [CrossRef]

13. Chevion, M.; Berenshtein, E.; Zhu, B.Z. The Role of Transition Metal Ions in Free Radical-Mediated Damage. In Reactive Oxygen Species in Biological Systems: An Interdisciplinary Approach; Gilbert, D.L., Colton, C.A., Eds.; Springer US: Boston, MA, USA, 2002; pp. 103-131. [CrossRef]

14. Orrenius, S.; Gogvadze, V.; Zhivotovsky, B. Mitochondrial oxidative stress: Implications for cell death. Annu. Rev. Pharmacol. Toxicol. 2007, 47, 143-183. [CrossRef]

15. Shigenaga, M.K.; Gimeno, C.J.; Ames, B.N. Urinary 8-hydroxy-2'-deoxyguanosine as a biological marker of in vivo oxidative DNA damage. Proc. Natl. Acad. Sci. USA 1989, 86, 9697-9701. [CrossRef] [PubMed]

16. Loffredo, L.; Perri, L.; Nocella, C.; Violi, F. Antioxidant and antiplatelet activity by polyphenol-rich nutrients: Focus on extra virgin olive oil and cocoa. Br. J. Clin. Pharmacol. 2017, 83, 96-102. [CrossRef]

17. Murador, D.; Braga, A.R.; Da Cunha, D.; De Rosso, V. Alterations in phenolic compound levels and antioxidant activity in response to cooking technique effects: A meta-analytic investigation. Crit. Rev. Food Sci. Nutr. 2018, 58, 169-177. [CrossRef] 
18. Psomiadou, E.; Tsimidou, M. Stability of virgin olive oil. 1. Autoxidation studies. J. Agric. Food Chem. 2002, 50, 716-721. [CrossRef] [PubMed]

19. Hanasaki, Y.; Ogawa, S.; Fukui, S. The correlation between active oxygens scavenging and antioxidative effects of flavonoids. Free Radic. Biol. Med. 1994, 16, 845-850. [CrossRef]

20. Yang, Q.Q.; Wei, X.L.; Fang, Y.P.; Gan, R.Y.; Wang, M.; Ge, Y.Y.; Zhang, D.; Cheng, L.Z.; Corke, H. Nanochemoprevention with therapeutic benefits: An updated review focused on epigallocatechin gallate delivery. Crit. Rev. Food Sci. Nutr. 2020, 60, $1243-1264$. [CrossRef] [PubMed]

21. Feng, C.Y.; Wang, W.W.; Ye, J.F.; Li, S.S.; Wu, Q.; Yin, D.D.; Li, B.; Xu, Y.J.; Wang, L.S. Polyphenol profile and antioxidant activity of the fruit and leaf of Vaccinium glaucoalbum from the Tibetan Himalayas. Food Chem. 2017, 219, 490-495. [CrossRef] [PubMed]

22. Zhu, B.Z.; Mao, L.; Fan, R.M.; Zhu, J.G.; Zhang, Y.N.; Wang, J.; Kalyanaraman, B.; Frei, B. Ergothioneine Prevents Copper-Induced Oxidative Damage to DNA and Protein by Forming a Redox-Inactive Ergothioneine-Copper Complex. Chem. Res. Toxicol. 2011, 24, 30-34. [CrossRef]

23. Sheng, Z.G.; Li, Y.; Fan, R.M.; Chao, X.J.; Zhu, B.Z. Lethal synergism between organic and inorganic wood preservatives via formation of an unusual lipophilic ternary complex. Toxicol. Appl. Pharmacol. 2013, 266, 335-344. [CrossRef]

24. Mao, L.; Huang, C.H.; Shao, J.; Qin, L.; Xu, D.; Shao, B.; Zhu, B.Z. An unexpected antioxidant and redox activity for the classic copper-chelating drug penicillamine. Free Radic. Biol. Med. 2020, 147, 150-158. [CrossRef] [PubMed]

25. Lopes, G.K.; Schulman, H.M.; Hermes-Lima, M. Polyphenol tannic acid inhibits hydroxyl radical formation from Fenton reaction by complexing ferrous ions. Biochim. Biophys. Acta BBA Gen. Subj. 1999, 1472, 142-152. [CrossRef]

26. Sestili, P.; Diamantini, G.; Bedini, A.; Cerioni, L.; Tommasini, I.; Tarzia, G.; Cantoni, O. Plant-derived phenolic compounds prevent the DNA single-strand breakage and cytotoxicity induced by tert-butylhydroperoxide via an iron-chelating mechanism. Biochem. J. 2002, 364, 121-128. [CrossRef]

27. Alam, M.A.; Subhan, N.; Hossain, H.; Hossain, M.; Reza, H.M.; Rahman, M.M.; Ullah, M.O. Hydroxycinnamic acid derivatives: A potential class of natural compounds for the management of lipid metabolism and obesity. Nutr. Metab. 2016, 13, 13. [CrossRef]

28. Bijalwan, V.; Ali, U.; Kesarwani, A.K.; Yadav, K.; Mazumder, K. Hydroxycinnamic acid bound arabinoxylans from millet brans-structural features and antioxidant activity. Int. J. Biol. Macromol. 2016, 88, 296-305. [CrossRef]

29. Firat, F.; Ozgul, M.; Uluer, E.T.; Inan, S. Effects of caffeic acid phenethyl ester (CAPE) on angiogenesis, apoptosis and oxidative stress in various cancer cell lines. Biotech. Histochem. 2019, 94, 491-497. [CrossRef]

30. Kuo, Y.Y.; Jim, W.T.; Su, L.C.; Chung, C.J.; Lin, C.Y.; Huo, C.; Tseng, J.C.; Huang, S.H.; Lai, C.J.; Chen, B.C.; et al. Caffeic Acid Phenethyl Ester Is a Potential Therapeutic Agent for Oral Cancer. Int. J. Mol. Sci. 2015, 16, 10748-10766. [CrossRef] [PubMed]

31. Ilhan, A.; Koltuksuz, U.; Ozen, S.; Uz, E.; Ciralik, H.; Akyol, O. The effects of caffeic acid phenethyl ester (CAPE) on spinal cord ischemia/reperfusion injury in rabbits. Eur. J. Cardiothorac. Surg. 1999, 16, 458-463. [CrossRef]

32. Irmak, M.K.; Fadillioglu, E.; Sogut, S.; Erdogan, H.; Gulec, M.; Ozer, M.; Yagmurca, M.; Gozukara, M.E. Effects of caffeic acid phenethyl ester and alpha-tocopherol on reperfusion injury in rat brain. Cell Biochem. Funct. Cell. Biochem. Its Modul. Act. Agents Dis. 2003, 21, 283-289. [CrossRef] [PubMed]

33. Russo, A.; Longo, R.; Vanella, A. Antioxidant activity of propolis: Role of caffeic acid phenethyl ester and galangin. Fitoterapia 2002, 73, S21-S29. [CrossRef]

34. Xu, D.; Huang, C.H.; Xie, L.N.; Shao, B.; Mao, L.; Shao, J.; Kalyanaraman, B.; Zhu, B.Z. Mechanism of unprecedented hydroxyl radical production and site-specific oxidative DNA damage by photoactivation of the classic arylhydroxamic acid carcinogens. Carcinogenesis 2019, 40, 1153-1163. [CrossRef] [PubMed]

35. Shao, B.; Mao, L.; Shao, J.; Huang, C.H.; Qin, L.; Huang, R.; Sheng, Z.G.; Cao, D.; Zhang, Z.Q.; Lin, L.; et al. Mechanism of synergistic DNA damage induced by caffeic acid phenethyl ester (CAPE) and $\mathrm{Cu}(\mathrm{II})$ : Competitive binding between $\mathrm{CAPE}$ and DNA with $\mathrm{Cu}(\mathrm{II}) / \mathrm{Cu}(\mathrm{I})$. Free Radic. Biol. Med. 2020, 159, 107-118. [CrossRef] [PubMed]

36. Cheng, Y.C.; Prusoff, W.H. Relationship between the inhibition constant (KI) and the concentration of inhibitor which causes 50 per cent inhibition (I50) of an enzymatic reaction. Biochem. Pharmacol. 1973, 22, 3099-3108.

37. Chao, X.J.; Tang, M.; Huang, R.; Huang, C.H.; Shao, J.; Yan, Z.Y.; Zhu, B.Z. Targeted live-cell nuclear delivery of the DNA 'light-switching' $\mathrm{Ru}(\mathrm{II})$ complex via ion-pairing with chlorophenolate counter-anions: The critical role of binding stability and lipophilicity of the ion-pairing complexes. Nucleic Acids Res. 2019, 47, 10520-10528. [CrossRef] [PubMed]

38. Huang, R.; Tang, M.; Huang, C.H.; Chao, X.J.; Yan, Z.Y.; Shao, J.; Zhu, B.Z. What Are the Major Physicochemical Factors in Determining the Preferential Nuclear Uptake of the DNA "Light-Switching" Ru(II)-Polypyridyl Complex in Live Cells via Ion-Pairing with Chlorophenolate Counter-Anions? J. Phys. Chem. Lett. 2019, 10, 4123-4128. [CrossRef] [PubMed]

39. Kinner, A.; Wu, W.; Staudt, C.; Iliakis, G. $\gamma$-H2AX in recognition and signaling of DNA double-strand breaks in the context of chromatin. Nucleic Acids Res. 2008, 36, 5678-5694. [CrossRef]

40. Jacobs, A. An intracellular transit iron pool. Ciba Found. Symp. 1976, 91-106. [CrossRef]

41. Kakhlon, O.; Cabantchik, Z.I. The labile iron pool: Characterization, measurement, and participation in cellular processes. Free Radic. Biol. Med. 2002, 33, 1037-1046. [CrossRef]

42. Jacobs, A. Low molecular weight intracellular iron transport compounds. Blood 1977, 50, 433-439. [CrossRef]

43. Grootveld, M.; Bell, J.D.; Halliwell, B.; Aruoma, O.; Bomford, A.; Sadler, P.J. Non-transferrin-bound iron in plasma or serum from patients with idiopathic hemochromatosis. Characterization by high performance liquid chromatography and nuclear magnetic resonance spectroscopy. J. Biol. Chem. 1989, 264, 4417-4422. [CrossRef] 
44. Adam, F.I.; Bounds, P.L.; Kissner, R.; Koppenol, W.H. Redox properties and activity of iron-citrate complexes: Evidence for redox cycling. Chem. Res. Toxicol. 2015, 28, 604-614. [CrossRef]

45. Petrat, F.; Rauen, U.; de Groot, H. Determination of the chelatable iron pool of isolated rat hepatocytes by digital fluorescence microscopy using the fluorescent probe, phen green SK. Hepatology 1999, 29, 1171-1179. [CrossRef] [PubMed]

46. Breuer, W.; Ermers, M.J.J.; Pootrakul, P.; Abramov, A.; Hershko, C.; Cabantchik, Z.I. Desferrioxamine-chelatable iron, a component of serum non-transferrin-bound iron, used for assessing chelation therapy. Blood 2001, 97, 792-798. [CrossRef] [PubMed]

47. Breuer, W.; Epsztejn, S.; Millgram, P.; Cabantchik, I.Z. Transport of iron and other transition metals into cells as revealed by a fluorescent probe. Am. J. Physiol. Cell Physiol. 1995, 268, C1354-C1361. [CrossRef]

48. Gao, G.; Zhang, N.; Wang, Y.-Q.; Wu, Q.; Yu, P.; Shi, Z.-H.; Duan, X.-L.; Zhao, B.-L.; Wu, W.-S.; Chang, Y.-Z. Mitochondrial ferritin protects hydrogen peroxide-induced neuronal cell damage. Aging Dis. 2017, 8, 458. [CrossRef]

49. Wang, Y.Q.; Chang, S.Y.; Wu, Q.; Gou, Y.J.; Jia, L.P.; Cui, Y.M.; Yu, P.; Shi, Z.H.; Wu, W.S.; Gao, G.F.; et al. The Protective Role of Mitochondrial Ferritin on Erastin-Induced Ferroptosis. Front. Aging Neurosci. 2016, 8, 9. [CrossRef] [PubMed]

50. Wang, Y.Q.; Wang, M.Y.; Fu, X.R.; Peng, Y.; Gao, G.F.; Fan, Y.M.; Duan, X.L.; Zhao, B.L.; Chang, Y.Z.; Shi, Z.H. Neuroprotective effects of ginkgetin against neuroinjury in Parkinson's disease model induced by MPTP via chelating iron. Free Radic. Res. 2015, 49, 1069-1080. [CrossRef]

51. Bullock, J.E.; Vagnini, M.T.; Ramanan, C.; Co, D.T.; Wilson, T.M.; Dicke, J.W.; Marks, T.J.; Wasielewski, M.R. Photophysics and redox properties of rylene imide and diimide dyes alkylated ortho to the imide groups. J. Phys. Chem. B 2010, 114, 1794-1802 [CrossRef]

52. Yang, S.; Bai, G.; Chen, L.; Shen, Q.; Diao, X.; Zhao, G. The interaction of phenolic acids with Fe(III) in the presence of citrate as studied by isothermal titration calorimetry. Food Chem. 2014, 157, 302-309. [CrossRef]

53. Park, J.; Morimoto, Y.; Lee, Y.M.; You, Y.; Nam, W.; Fukuzumi, S. Scandium ion-enhanced oxidative dimerization and Ndemethylation of N,N-dimethylanilines by a non-heme iron(IV)-oxo complex. Inorg. Chem. 2011, 50, 11612-11622. [CrossRef]

54. Lee, C.Y.; Nanah, C.N.; Held, R.A.; Clark, A.R.; Huynh, U.G.; Maraskine, M.C.; Uzarski, R.L.; McCracken, J.; Sharma, A. Effect of electron donating groups on polyphenol-based antioxidant dendrimers. Biochimie 2015, 111, 125-134. [CrossRef] [PubMed]

55. Imai, K.; Nakanishi, I.; Ohkubo, K.; Ohno, A.; Mizuno, M.; Fukuzumi, S.; Matsumoto, K.I.; Fukuhara, K. Synthesis and radical-scavenging activity of C-methylated fisetin analogues. Bioorg. Med. Chem. 2019, 27, 1720-1727. [CrossRef] [PubMed]

56. Yavin, E.; Kikkiri, R.; Gil, S.; Arad-Yellin, R.; Yavin, E.; Shanzer, A. Synthesis and biological evaluation of lipophilic iron chelators as protective agents from oxidative stress. Org. Biomol. Chem. 2005, 3, 2685-2687. [CrossRef] [PubMed]

57. Gerogianni, P.S.; Chatziathanasiadou, M.V.; Diamantis, D.A.; Tzakos, A.G.; Galaris, D. Lipophilic ester and amide derivatives of rosmarinic acid protect cells against $\mathrm{H} 2 \mathrm{O} 2$-induced DNA damage and apoptosis: The potential role of intracellular accumulation and labile iron chelation. Redox Biol. 2018, 15, 548-556. [CrossRef] [PubMed]

58. Imbert, D.; Baret, P.; Gaude, D.; Gautier-Luneau, I.; Gellon, G.; Thomas, F.; Serratrice, G.; Pierre, J.L. Hydrophilic and lipophilic iron chelators with the same complexing abilities. Chem. Eur. J. 2002, 8, 1091-1100. [CrossRef]

59. Kitsati, N.; Fokas, D.; Ouzouni, M.-D.; Mantzaris, M.D.; Barbouti, A.; Galaris, D. Lipophilic caffeic acid derivatives protect cells against H2O2-Induced DNA damage by chelating intracellular labile iron. J. Agric. Food Chem. 2012, 60, 7873-7879. [CrossRef]

60. Cabrera, C.; Artacho, R.; Giménez, R. Beneficial effects of green tea-A review. J. Am. Coll. Nutr. 2006, 25, 79-99. [CrossRef]

61. Vinson, J.A.; Su, X.; Zubik, L.; Bose, P. Phenol antioxidant quantity and quality in foods: Fruits. J. Agric. Food Chem. 2001, 49, 5315-5321. [CrossRef]

62. Vinson, J.A.; Hao, Y.; Su, X.; Zubik, L. Phenol antioxidant quantity and quality in foods: Vegetables. J. Agric. Food Chem. 1998, 46, 3630-3634. [CrossRef]

63. Vinson, J.A.; Proch, J.; Zubik, L. Phenol antioxidant quantity and quality in foods: Cocoa, dark chocolate, and milk chocolate. J. Agric. Food Chem. 1999, 47, 4821-4824. [CrossRef] [PubMed]

64. Zhu, B.Z.; Chao, X.J.; Huang, C.H.; Li, Y. Delivering the cell-impermeable DNA 'light-switching' Ru(II) complexes preferentially into live-cell nucleus via an unprecedented ion-pairing method. Chem. Sci. 2016, 7, 4016-4023. [CrossRef] [PubMed]

65. Wu, W.M.; Lu, L.; Long, Y.; Wang, T.; Liu, L.; Chen, Q.; Wang, R. Free radical scavenging and antioxidative activities of caffeic acid phenethyl ester (CAPE) and its related compounds in solution and membranes: A structure-activity insight. Food Chem. 2007, 105, 107-115. [CrossRef]

66. Rice-evans, C.A.; Miller, N.J.; Bolwell, P.G.; Bramley, P.M.; Pridham, J.B. The relative antioxidant activities of plant-derived polyphenolic flavonoids. Free Radic. Res. 1995, 22, 375-383. [CrossRef]

67. Halliwell, B.; Gutteridge, J.M.C. Role of free radicals and catalytic metal ions in human disease: An overview. Methods Enzymol. 1990, 186, 1-85.

68. Khokhar, S.; Apenten, R.K.O. Iron binding characteristics of phenolic compounds: Some tentative structure-activity relations. Food Chem. 2003, 81, 133-140. [CrossRef]

69. Sestili, P.; Guidarelli, A.; Dachà, M.; Cantoni, O. Quercetin prevents DNA single strand breakage and cytotoxicity caused by tert-butylhydroperoxide: Free radical scavenging versus iron chelating mechanism. Free Radic. Biol. Med. 1998, 25, 196-200. [CrossRef]

70. Aherne, S.A.; O'Brien, N.M. Mechanism of protection by the flavonoids, quercetin and rutin, against tert-butylhydroperoxide-and menadione-induced DNA single strand breaks in Caco-2 cells. Free Radic. Biol. Med. 2000, 29, 507-514. [CrossRef] 
71. Coleman, J.B.; Gilfor, D.; Farber, J.L. Dissociation of the accumulation of single-strand breaks in DNA from the killing of cultured hepatocytes by an oxidative stress. Mol. Pharmacol. 1989, 36, 193-200.

72. Byrnes, R.W. Inhibition of hydroperoxide-induced DNA single-strand breakage by 1, 10-phenanthroline in HL-60 cells: Implications for iron speciation. Arch. Biochem. Biophys. 1996, 332, 70-78. [CrossRef] [PubMed]

73. Richardson, D. Iron chelators as therapeutic agents for the treatment of cancer. Crit. Rev. Oncol. Hematol. 2002, 42, 267-281. [CrossRef]

74. Richardson, D. Potential of iron chelators as effective antiproliferative agents. Can. J. Physiol. Pharmacol. 1997, 75, 1164-1180. [CrossRef] [PubMed]

75. Buss, J.L.; Greene, B.T.; Turner, J.; Torti, F.M.; Torti, S.V. Iron chelators in cancer chemotherapy. Curr. Top. Med. Chem. 2004, 4, 1623-1635. [CrossRef] [PubMed] 